UNIVERSIDADE DE SÃO PAULO

INSTITUTO DE RELAÇÕES INTERNACIONAIS

GABRIEL CHAGAS BRASIL

Competitive Aspects of the Brazilian Banking Sector: Has it Repealed Foreign Competition? 
GABRIEL CHAGAS BRASIL

\title{
Competitive Aspects of the Brazilian Banking Sector: Has it Repealed Foreign Competition?
}

\author{
Dissertação apresentada ao Programa de Pós-Graduação em \\ Relações Internacionais do Instituto de Relações \\ Internacionais da Universidade de São Paulo, para a \\ obtenção do título de Mestre em Ciências. \\ Orientador(a): Profa. Dra. Maria Antonieta Del Tedesco \\ Lins
}

\section{Versão corrigida}

A versão original se encontra disponível na Biblioteca do Instituto de Relações Internacionais 
Autorizo a reprodução e divulgação total ou parcial deste trabalho, por qualquer meio convencional ou eletrônico, para fins de estudo e pesquisa, desde que citada a fonte.

\title{
Catalogação na Publicação
}

Instituto de Relações Internacionais da Universidade de São Paulo

\author{
Catalogação na publicação \\ Serviço de Biblioteca e Documentação \\ Instituto de Relações Internacionais da Universidade de São Paulo
}

Brasil, Gabriel Chagas

Competitive aspects of the Brazilian banking sector: has it repealed foreign competition / Gabriel Chagas Brasil ; orientadora: Maria Antonieta Del Tedesco Lins. - São Paulo, 2019.

$67 \mathrm{p}$.

Dissertação (Mestrado) - Instituto de Relações Internacionais. Universidade de São Paulo, São Paulo, 2019.

1. Integração financeira internacional 2. Internacionalização bancária 3. Bancos estrangeiros 4. Mercados emergentes 5. Proteção endógena I. Lins, Maria Antonieta Del Tedesco, orient. II. Título.

$$
\mathrm{CDD}-337.1
$$




\section{Reconhecimentos}

Esse trabalho não teria sido possível sem o apoio dos meus pais, Ronan e Lena, que não apenas seguem acreditando nos meus sonhos como também, generosamente, investem neles - desde sempre. Sou grato também pela companhia do meu irmão, Vinícius, que foi de grande ajuda nessa minha inesperada trajetória acadêmica.

Agradeço à minha orientadora, professora Tuca, pela disponibilidade, pela atenção e por compreender o desafio que foi conduzir esse trabalho em paralelo aos meus outros projetos profissionais. Agradeço também à professora Adriana Schor, que me acolheu no Instituto de Relações Internacionais quando eu achava que, como economista, teria pouco espaço ali (estava enganado). Tenho muito orgulho de ter podido contar com a ajuda das duas - mulheres que inspiram, sobretudo, pela sua competência e pelo respeito que têm pelos seus alunos.

Sou, ainda, muito grato à Universidade de São Paulo, uma instituição pública de excelência na qual estudar foi um grande privilégio. Espero que este trabalho expresse um pouco da certeza que tenho de que, a despeito dos desafios, continua valendo a pena investir em gente - especialmente quando a sociedade parece carecer cada vez mais da ciência e, sobretudo, do progresso (cívico, moral) que ela traz consigo.

- e, claro, aos meus avós, Haroldo e Elyanne, as maiores referências intelectuais e cidadãs que sempre terei. 

Paulo, São Paulo, 2019.

\begin{abstract}
This paper discusses the low participation of foreign banks in the Brazilian market over the last two decades. Although the country went through an explicit and, to some extent, accelerated process of opening up of this sector in the 1990s, foreign banks have presented market shares that have never been historically expressive in relative terms - compared to those of their local competitors and to those presented by foreign banks in other emerging countries in the same period. Moreover, since 2001 their market shares have fallen significantly. This research analyzes this phenomenon from the evaluation of structural elements of the Brazilian market, the influence exerted by the particular presence of large state-owned banks in the country and, finally, from the behavior of local private banks in relation to their endogenous protection strategies towards foreign competitors. Additionally, a brief case study based on the comparison between two foreign banks with opposite trajectories in Brazil, HSBC Brasil and Santander Brasil, is presented illustratively, in order to complement the proposed discussion. The conclusions of the paper indicate that the competitive environment of the Brazilian banking market has not been favorable, nor even neutral, for foreign players, and therefore their low participation levels are not essentially due to external phenomena (which could be associated, for example, with scenarios of deglobalization or scale-downs). Evidence suggest that foreign banks in Brazil have suffered to a significant extent from the country's structural and institutional particularities, and have been directly targeted, in competitive terms, by their local competitors.
\end{abstract}

Palavras-chave: International Financial Integration. Banking Internationalization. Foreign Banks. Emerging Markets. Endogenous Protection. 
Resumo: Este trabalho discute a baixa participação de bancos estrangeiros no mercado brasileiro nas últimas duas décadas. Embora o país tenha passado por um processo explícito e, até certo ponto, acelerado de abertura desse setor na década de 1990, bancos estrangeiros apresentaram participações de mercado que nunca chegaram a ser expressivas em termos relativos historicamente - em comparação àquelas dos seus competidores locais (privados e estatais) e àquelas apresentadas por bancos estrangeiros em outros países emergentes. Além disso, desde 2001 elas têm caído consideravelmente. A presente pesquisa então analisa tal fenômeno a partir da avaliação de elementos estruturais do mercado brasileiro, da influência exercida pela presença particular de grandes bancos públicos no país e, finalmente, do comportamento dos bancos privados locais com relação às suas estratégias de proteção endógena frente aos seus pares estrangeiros. Adicionalmente, um breve estudo de caso feito a partir da comparação entre dois bancos estrangeiros com trajetórias opostas no país, HSBC Brasil e Santander Brasil, é apresentado ilustrativamente, com o objetivo de complementar a discussão proposta. As conclusões do trabalho indicam que o ambiente competitivo do mercado bancário brasileiro não tem sido favorável para players estrangeiros, e que portanto sua baixa participação não é, essencialmente, um fenômeno externo (associado, por exemplo, a um cenário de deglobalização ou de scale-down). Evidências neste discutidas sugerem que os bancos estrangeiros no Brasil têm sofrido em escala significativa com as particularidades estruturais e institucionais do país, sendo, ainda, diretamente hostilizados, em termos competitivos, por seus concorrentes locais.

Palavras-chave: Integração Financeira Internacional. Internacionalização Bancária. Bancos Estrangeiros. Mercados Emergentes. Proteção Endógena. 


\section{List of tables and charts}

Chart 1 - Assets Share by Bank Ownership, 1994-2018 ................................ 14

Chart 2 - Foreign Banks Assets Share vs Foreign Banks / Total Banks, 2000-18 ................ 16

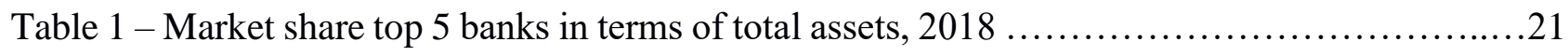

Chart $3-\mathrm{CR}_{\mathrm{k}} 5$ Index, Total Banks and Foreign Banks Market Share, 2000-18 ................. 23

Chart 4 - HH Index vs Foreign Bank Market Share, 2000-2018 ........................... 24

Table 2 - Market and Branches Share per Bank Ownership, 2018 ........................... 25

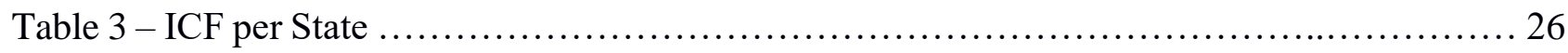

Chart 5 - Total branches per bank ownership, 2000-2018 _.............................. 27

Chart 6 - Distribution of Loans per Bank Ownership, 2000-18 .............................. 33

Table 4 - After Crisis Market Share per Ownership, 2007-13 ........................... 34

Table 5 - Largest donors among banks for presidential final campaigns, 2002-2014 _........... 42

Table 6 - Febraban Presidents, selected years........................................44

Chart 7 - Total Assets per Year, Santander vs HSBC, 2000-15, in BRL Millions ................ 47

Chart 8 - Accumulated Net Profit (starting in 2000), 2000-14; in BRL Millions .................. 55

Chart 9 - Branches share over total, Santander vs HSBC ................................... 55 


\section{Table of contents}

1 INTRODUCTION 9

2 FOREIGN BANK PRESENCE IN EMERGING MARKETS 11

2.1 Implications and stylized facts $\quad 12$

2.2 The Brazilian case: a brief historical contextualization and the current panorama 14

3 THE POLITICAL ECONOMY OF THE BRAZILIAN BANKING SYSTEM: ITS MARKET STRUCTURE AND COMPETITIVE DYNAMICS 18

3.1 Market structure and institutional arrangement: competitiveness, organization and the accommodation of foreign players

3.2 Public Banks: after crisis` role and impact over foreign-banks competition

3.3 Private banks: strategic behavior, consolidation and endogenous protection

4 CASE STUDY: A COMPARISON BETWEEN SANTANDER BRASIL, HSBC BRASIL 47

4.1 Santander Brasil

4.2 HSBC Brasil

4.3 Comparison

5 FINAL CONSIDERATIONS 


\section{INTRODUCTION}

Unlike most of its emerging market main peers, particularly in Latin America, Brazil has never had significant levels of foreign banks participation in its financial market. Historically, and despite a promising increase during opening in the 1990s, the Brazilian banking sector competitive landscape has been largely dominated by domestic players - both state-owned and private - over the past two decades. In addition to never having reached significant levels of market share, the aggregate participation of foreign banks in the country has substantially declined since its peak, in 2001, when it reached $26.5 \%$ of total banking assets. In 2018, while they accounted for only $15.6 \%$ of the total, domestic private institutions held $43.2 \%$ and the state-owned banks accounted for $41.1 \%$ of the assets in the Brazilian financial sector ${ }^{1}$.

Although this phenomenon of domestic dominance poses relevant implications to the dynamics of financial systems - which range from impacts to their stability levels to the country's interest rates (thus impacting the economy more widely) - literature on the reasons behind the low levels of participation of foreign banks in Brazil is scarce. Most works on the subject are focused on the analysis of the phenomenon's potential effects in financial variables, such as spread levels and market power, rather than on understanding the conditioning elements associated to the competitive hardships facing foreign players in the country's banking sector, which motivates this research.

Nevertheless, as this topic is ultimately part of a segment of the comprehensive international financial integration literature and, more directly, the banking internationalization theoretical frameworks, there is a wide variety of contributions that can be fortuitously discussed in order to provide us with a better contextualization of drivers of foreign banks' entry (and stay) in emerging economies such as Brazil's.

In addition to tracking isolated events and structural trends in the country's banking sector over the past two decades that help elucidate its competitive dynamics, particularly regarding incentives or disincentives for foreign competition, this work also discusses legal and institutional aspects of the sector that may exert influence on this panorama. This work's ultimate goal, then,

\footnotetext{
1 In this paper, the market share of each bank ownership category in Brazil was calculated based on the total assets of each category (state, private and foreign) over the banking sector's total assets, according to the data by the Brazilian Central Bank (BCB) database ("IF. Data").
} 
is to discuss the hypothesis of the presence of significant barriers to foreign competition in the sector, as opposed to explaining the two decades-old low participation of foreign banks in Brazil with external factors, such as deglobalization waves and spill-over effects of the 2007-08 financial crisis, as further discussed. The paper is organized as follows:

Section 2 presents stylized facts and implications discussed in the literature about foreign banks' entry in emerging markets, with particular focus on the drivers and constraints of this process. It also includes a brief presentation of the historical context and of the current situation of the participation of foreign players in the Brazilian banking sector - from its liberalization in the 1990s to the current period, with data up to 2018.

Section 3 proposes a thematic discussion and an in-depth analysis of the elements that may have effectively constituted barriers to the competitive performance of foreign banks in the Brazilian market over the analyzed period. These elements are divided into three groups:

(i) a discussion on the structural and legal and institutional competitive aspects of the Brazilian banking sector that may be related to market barriers to foreigners;

(ii) an assessment of the influence of Brazil's state-owned banks on these players' competitiveness; and

(iii) an overview of the behavior of private banks - in strategic and institutional terms with regards to the competitive environment and its protection strategies against external competition.

Section 4 presents a brief case study that compares the trajectory of two of the largest foreign banks that have operated in Brazil, Spanish Santander and British HSBC. These have presented opposite results on the terms of their performances since their entry in the Brazilian market: while Santander has ranked among the top 5 largest banks in the country over the past years, HSBC sold its operations in Brazil to its domestic competitor Bradesco in 2015, after consecutive disappointing results in the years before. Although this case study is presented with purposes limited to complementing the discussion made in section 3 (the main focus of this paper), it also helps illustrate and verify, at least superficially, the consistency of the arguments made on that section.

Final considerations are presented in section 5. 


\section{FOREIGN BANK PRESENCE IN EMERGING MARKETS}

\subsection{Implications and stylized facts}

Literature on the foreign bank entry in emerging countries' banking systems generally assesses its effects on variables such as credit supply, interest rates, market efficiency levels and the competitiveness of its players. Additionally, it often describes relationships that go beyond the financial dimension, pertaining, in different levels, to the real economy - such as economic growth and development. In general, as Clarke et al. (2003) put, patterns concerning these effects tend not to be homogeneous: they depend, among other factors, on the mechanism through which entry was conducted (POGSHOYAN \& POGSHOYAN, 2010) ${ }^{2}$, on the time frame analyzed ${ }^{3}$ (CLAESSENS et al, 2000) and on the development level of each country, for instance.

According to Haas \& Van Levyveld (2003) and Cull \& Peria (2010), the analysis of internal specific conditions is also essential to understanding the dynamics of participation of foreign financial institutions in national markets. Cull \& Peria, in particular, highlight three main driving reasons for this process: (i) the presence of local and relevant opportunities' investments portfolios; (ii) the level and the nature of the barriers to market entry; and (iii) the availability of mechanisms to foreign players to mitigate information problems in these markets. ${ }^{4}$ These drivers - together with economic and institutional aspects of each country, as will be further discussed - help us understand part of the financial system dynamics towards the financial liberalization phenomenon. After all, what are the stylized facts related to it?

Segments of the literature discuss this topic by first going over the reasons that drive banks, from one side, to go multinational and, from the other side, countries to promote their entries into their financial markets, both proactively or reactively.

On the banks' perspective, authors such as Cunha and Boehe (2008) and Boch, Koch and Koetter (2011) converge on indicating that the main reasons for explaining the internationalization

2 Pogshoyan \& Pogshoyan discuss the implications that different entry strategies (Greenfield and M\&A, essentially) may have on the success of the initiative. They argue, in general terms, that entries based on the first approach are generally more successful than those based on mergers and acquisitions.

3 These authors estimate that the impact of the presence of foreign entrants changes throughout the maturation process of their operations: although these players require some time to adapt their operations to the new market, their presence generally affects domestic competitors since its beginning.

$4 \quad$ In the case of the third reason, these are instruments that can be used by new entrants to compensate for the asymmetry of access to the information that they tend to have vis-à-vis domestic players and which would represent a challenge to their entry process. 
processes of financial conglomerates vary: from the expected search for competitive advantages capable of increasing their profit margins directly to the fact that, strategically, it makes commercial sense to accompany the internationalization movements of their clients. This point is also particularly endorsed by Bhattacharya (1994), who further argues that, in addition to such motivations, banks look into new markets: (i) seeking opportunities related to possible inefficiencies of domestic players; (ii) to take advantage of regulatory arbitrage strategies; and, finally, (iii) to improve the composition of their portfolios in the sense that internationalization can mean diversification.

Although other motivations are discussed in the literature - without much obvious dissent, it is worth mentioning - Golapan (2015) summarizes them through an approach that reinforces that, by their economic nature, banking tends to have marginal cost structures that justify, in the sense of their scalability, the risks of their expansion into new markets. There are, after all, scale and scope gains opportunities in this process in several dimensions (TELES, 2011).

It should be noted, however, that disadvantages in the internationalization strategy for banks are also discussed in the literature, usually focusing on the notion that expansion into new (especially emerging) markets may involve risks that are not always clearly identified by them at the beginning. ${ }^{5 .}$ However, these disadvantages do not seem to surpass the benefits they end up finding, on average - which explains, for example, part of the worldwide wave of internationalization experienced by the large conglomerates in the 1990s and 2000s.

From the countries' perspective, in turn, there is also a variety of reasons why attracting and retaining foreign financial institutions can be fortuitous. According to Paula (2007), when opening their banking systems, national economies can benefit from greater access to foreign savings, greater resilience to exogenous shocks, greater chances of incorporating and developing new technologies, and a greater propensity to identify increases in the efficiency levels of the sector (PAULA, 2007 apud LEVINE, 1996; PEEK; ROSENGREEN, 2000; WALTER; GRAY, 1983).

Fachada (2008) argues that the entry of foreign banks in general leads to positive effects in three main dimensions: (i) in the sector's efficiency level, which tends to increase due to the

5 Buch, Koch e Koetter (2011) argue that the effects of internationalization initiatives are heterogeneous among banks: they depend essentially on their sizes and types - in addition to, of course, on the strategies through which they are carried over. 
reduction of systemic costs and the implementation of good management practices; (ii) in market financing patterns, which tend to assume dynamics that combine greater access to credit and greater stability - with the caveat that credit may concentrate in companies with better credit risk ratings (larger conglomerates, generally); and (iii) in the stability of the system, which, according to empirical data discussed by the author, seems to become less vulnerable to shocks and crises after its opening to foreign players.

On the other hand, there are also important arguments on disadvantages for countries in this context. The ones that are probably the most prominent are usually related to the point made by Stiglitz (1993), who argues that the entry of foreign competitors may not only affect negatively the competitiveness of domestic competitors in the financial sector, but it can also harm the competitiveness of firms in the productive sector, as foreign banks tend to centralize their loans' portfolios in large conglomerates (reinforcing the importance of Fachada's caveat). This thesis is endorsed, for instance, by Agènor (2003), who similarly shows that the entry of foreign banks can generate wider changes in capital allocation that may not be desirable for the domestic economy in the medium-to-long term.

In macroeconomic terms - and as part of the international financial integration phenomenon -, bank internationalization (here discussed through the analysis of the presence of foreign banks in domestic markets) tends to be, at least to some extent, controversial, as Kose et al (2011) put it. With respect to its materialization through the entry of multinational banks in emerging countries, the literature indicates different advantages and disadvantages associated with the process - for banks and countries - with a reasonable dominance of the former, despite the fact that case-focused works continue to add to this debate. The Brazilian case, whose particularity gives rise to this work, is discussed from its historical contextualization and current panorama in the following sub-section.

\subsection{The Brazilian case: a brief historical contextualization and the current panorama}

The literature on the liberalization of the Brazilian financial system, produced in particular from the beginning of the 1990s, centrally addresses the constraints and impacts associated with at least two major and closely associated events: the worldwide (and particularly in Latin America) implementation of liberal policies and economic guidelines aimed at promoting macroeconomic stability, in light of the Washington Consensus (WILLIAMSON, 1989), in addition to the Real 
Plan $^{6}$ together with a set of federal government bank restructuring programs (in particular PROER ${ }^{7}$ and $\mathrm{PROES}^{8}$ ) and a fiscal rearrangement process conducted by the Brazilian government between 1994 and 2002. These were responsible for transforming the Brazilian banking market scenario by promoting the stabilization of the monetary system and the consolidation of banks in financial difficulties $^{9}$ into economically sounder institutions, also fostering the development of new governance practices, more in line with those used internationally (FACHADA, 2008).

Nevertheless, in spite of the successful structuring of the country's banking and financial system in the 1990s, which stimulated the entry of foreign players into the country in subsequent years, the participation of these institutions over the past 25 years has been erratic on the terms of its consolidation - which has never happened, as indicated in Chart 1.

Chart 1 - Assets Share by Bank Ownership, 1994-2018

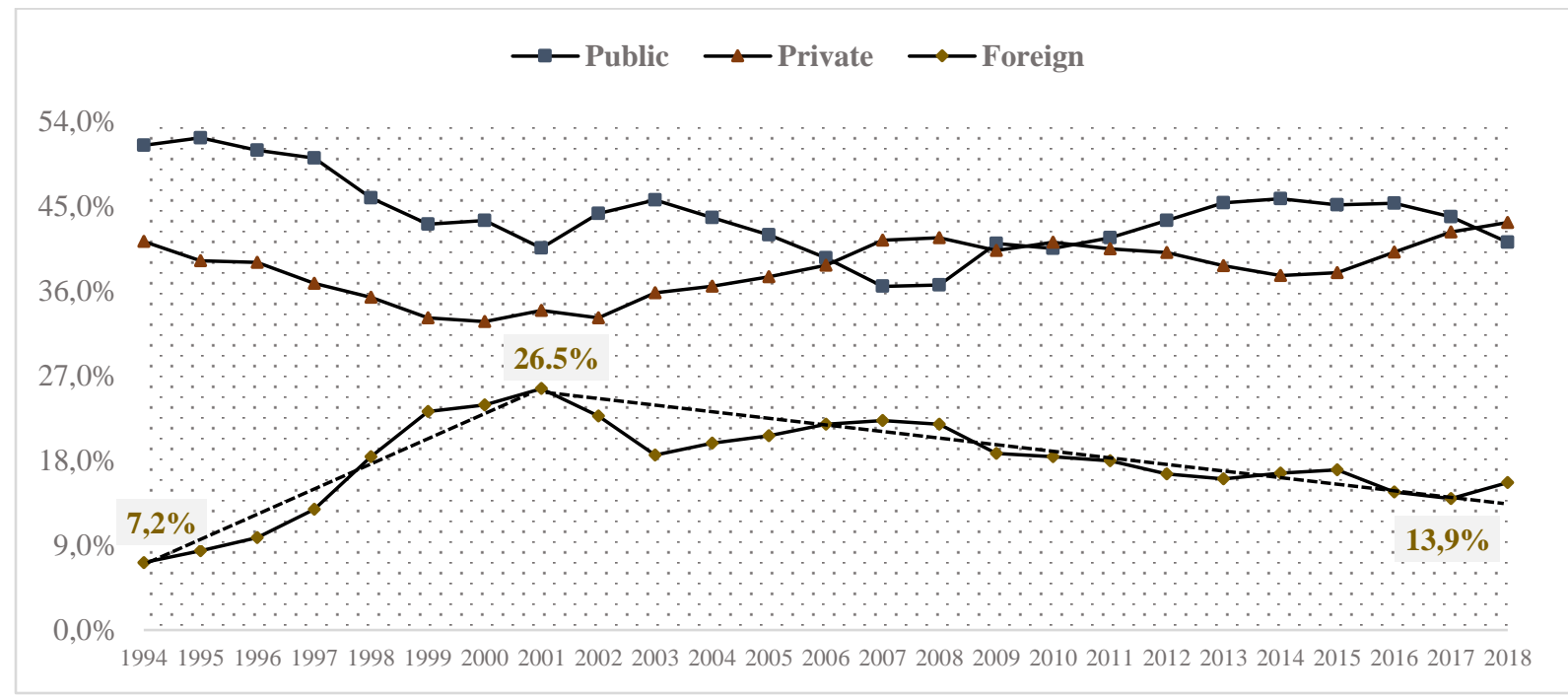

Source: BCB, elaborated by the author

6 The Real Plan relates to the internationalization of the Brazilian banking system insofar as it established institutional and structural bases relevant to its viability (CARVALHO, 2000).

$7 \quad$ According to Paula (1998, p. 10), PROER is responsible "to a large extent [of] the success in organizing the adjustment of the Brazilian banking system to conditions of price stability". It is a program conducted with the notion, according to Fachada (2008) consensual at the time, that the program's target public banks were "recurrent vehicles of fiscal indiscipline that should be definitely controlled".

$8 \quad$ Similar to PROER, but also focused on state institutions.

$9 \quad$ According to Maia (1999), a central part of the difficulties faced by players in the Brazilian banking system at this time came from the loss of the so-called "Inflation Revenues", substantially reduced after the success of the Real Plan in the fight against inflation. According to his data, in the early 1990s these accounted for nearly $40 \%$ of all financial intermediation revenues in the system. After the monetary stabilization in 1994, they accounted for only $2 \%$ - and became insignificant as early as 1995 . 
As evidenced by the chart, the entry movement of foreign players in the 1990s has never consolidated itself as a trend or a clear characteristic of the banking sector in the country, despite its sharp acceleration in the late 1990s. While this non-consolidation by itself would already be a curious phenomenon - considering the country's a priori attractiveness for foreign banks (in demographic, market size potential terms) - the consistent decrease of their market share after its peak, in 2001, can be regarded as an even more anomalous movement, or at least an unexpected phenomenon, ceteris paribus, considering the panoramas of other Latin American countries, where foreign bank participation has been historically much higher, such as in Argentina, Peru, Chile and Mexico.

For instance, in 2001, during Brazil's peak of foreign bank participation, at 26\%, the market share of foreign banks was at 51\% in Mexico, $41 \%$ in Peru, $40 \%$ in Argentina, and 39\% in Chile $\left(\right.$ CULL et. al 2017) ${ }^{10}$. Although data using the same criteria for measuring market share per bank ownership for all these countries in more recent years has not been available (to the best of this author's knowledge), isolated data (per country, individually, in different recent years) suggest that the levels of foreign bank participation in these economies remain substantially above the Brazilian ones. Data by the World Bank's Global Financial Development Database show that in 2013, foreign-banks accounted for $92 \%$ of all banking assets in Uruguay, while accounting for $70 \%$ in Mexico, $51 \%$ in Paraguay and Peru, 33\% in Chile, $25 \%$ in Argentina, $18 \%$ in Venezuela and $15 \%$ in Brazil.

Fachada (2008) suggests a characterization for the Brazilian trajectory presented in Chart 1 based on a division in four distinct moments, which essentially describes the inflections that occurred in this process in light of the economic events and conjunctures associated with it. In sum, this author evaluates that this course responded in a reasonably sensitive way to a variety of movements of external and domestic nature that were experienced by the country over this period - showing, ultimately, that the participation of foreign banks in Brazil has never been a phenomenon guaranteed by its own virtues (as discussed in the previous section), but always dependent on a set of dominant variables and circumstances driving its consolidation.

10 Although for this year data by the BCB indicate a foreign bank market share in total assets in Brazil at $25.6 \%$, the data by Cull, Pería and Verier (2017) indicate a slightly different percentage, likely related to minor criteria differences or updates, at $23 \%$. 
The period after the 2007-08 financial crises presents an even more emblematic situation in the Brazilian market that should be highlighted, given the sharp reduction in the participation of foreign banks in the country in terms of their total market share. Over the ten years between 2007 and 2017, it fell by almost half, from $22.2 \%$ to $13.9 \%$ as illustrated by Chart 1 - a percentage drop that is much higher than that experienced by its Latin American neighbors, for example, where foreign participations went from $34 \%$ to levels around $26 \%$ in the same period, in average.

That is: not only has Brazil never reached the levels of openness experienced by its pairs, but it has also concentrated domestically the market assets in a much larger proportion in recent years compared to them.

This trend becomes even more expressive when analyzed in relative terms: in 2000, when foreigners` share was $23.9 \%$ of the total assets of the banking market, foreign institutions accounted for $31 \%$ of all banks ( 40 out of 129). In 2018, they accounted for $41 \%$ of all institutions (39 out of 94), but their share fell down to $15.6 \%$. It shows that even after increasing its representativeness among total banks, the market share of foreign banks has reduced, indicating a significant competitive difficulty facing these banks over these past 18 years.

Chart 2 - Foreign Banks Assets Share vs Foreign Banks / Total Banks, 2000-18

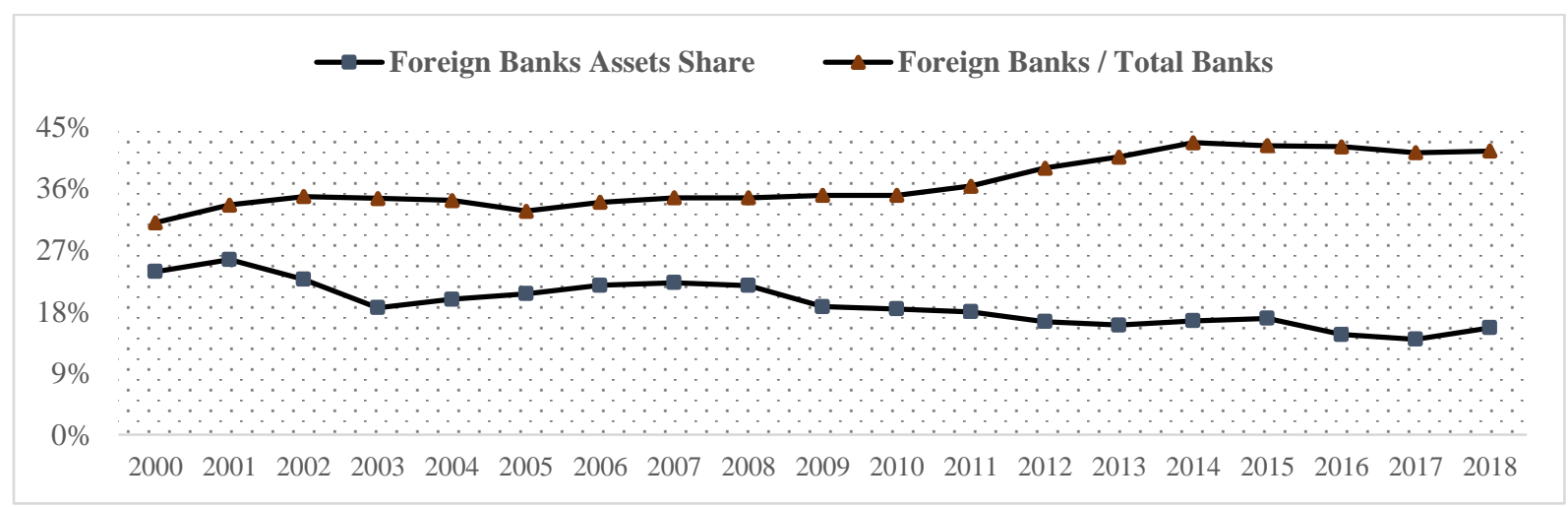

Source: BCB, developed by the author

Specifically with regards to the last decade's trajectory, when the foreign banks market share decreased the most, it should also be noted that this trend can, a priori, be associated to two consecutive movements, as indicated by Graph 1: (i) the increase of the market share of the public banks between 2007 and 2014, and (ii) the reversion of this trend after 2015, when domestic private players took over almost all of the share lost by foreigners. Although this work has used series of data starting in previous years in order to promote a discussion in a broader perspective (starting 
in 2000 or in 1994, depending on the availability of the data), the years between 2007 and 2018 were those of its greater focus given the expressiveness of the downward movement in terms of participation of foreign banks during this period - which is presented and discussed in the following sections. 


\section{THE POLITICAL ECONOMY OF THE BRAZILIAN BANKING SYSTEM: ITS MARKET STRUCTURE AND COMPETITIVE DYNAMICS}

In discussing the reasons why several major international institutions discontinued their activities in Brazil, or at least relevant shares of their operations, since the 2000s, Fachada (2008) discusses the recurrent evaluation that this phenomenon was mainly due to the allegedly bad conditions presented by most of the banks that were acquired by the foreign players in the context of their entrances. According to this interpretation, most of the decrease in market share pertaining to foreign banks in the Brazilian market over the past two decades would be related to the poor quality of the assets that they had initially acquired (through M\&A operations), which would have hampered the competitiveness of these institutions vis-à-vis their domestic competitors in the medium-term.

However, still according to Fachada, although this argument is valid for some of the foreign bank exits, there are also relevant cases that contradict it, such as that of the English conglomerate HSBC - an important example due to its notorious representativeness, as will be discussed shortly in section 4 - or even of players that had been historically established in the country, such as the American BankBoston and the also British Lloyds ${ }^{11}$. In light of these contradictions and other cases, the econometric model developed by Fachada indicates that it seems in fact naive to attribute the exits of the foreign banks over the past decade only - or to a heightened degree - to the conditions of the domestic players they acquired at the time of their entries.

In general, his tests indicated that, at first, low profitability levels may be, ultimately, an important element in the exit decision of these institutions, although it does not indicate per se "significant relationship between time and mode of entry and exit". His results indicate that foreign banks in Brazil have not been able to benefit from gains in scale - which certainly should be considered in the discussion on their exits (and on their decreasing market shares), at it is, simultaneously, an indicative of their lack of competitiveness in the country's market and a possible strategic reason for this phenomenon.

11 British HSBC's representativeness is in particular due to its notorious global relevance and, in Brazil, its presence among the largest banks in the country, having reached eighth place among the largest asset holders in the country in 2009 (BCB). BankBoston was originally established in Brazil in 1947 and was one of the oldest foreign banks operating in Brazil. Lloyds Bank, in turn, began operations in the country even earlier in 1863. 
Similarly, Gomes, Oliveira and Matias (2017) argue that between 2006 and 2013 domestic banks dominated the efficiency indicators of the country's banking system in comparison to their foreign competitors. They point out that outsiders generally suffer from higher costs in their operations, particularly in relation to funding and personnel recruitment, which can affect directly their efficiency levels ${ }^{12}$.

These authors also argue that the 2007-08nternational crisis was more challenging for foreign banks than for domestic banks in Brazil, since foreign banks not only had to deal with the challenges in their home countries but also had to face competitive landscape marked by the Brazilian public bank's notorious countercyclical agenda in the country (further discussed) - a thesis also endorsed by Oliveira, Schiozer and Leão (2012), who argue that the crisis was more "intense and lasting", as they put it, for foreign banks than for the domestic ones in Brazil.

Mettenheim (2010), in turn, summarizes the competitive failure of foreign banks - in particular in comparison with domestic state-owned banks - through factors associated with their portfolios' structures and other competitive barriers, which would together form a framework capable of explaining this phenomenon. His work does not, however, detail the transmission mechanisms of these variables in this scenario.

Regarding the possible hypothesis that explains the reduction of the relevance of foreign banks in Brazil as due to a supposed wave of "deglobalization" - that is, an external movement of global scale down by multinational conglomerates due to the 2007-08 financial crisis, and not as essentially endogenous dynamics - McCauley et al. (2017) are incisive in showing that such phenomenon seems to be restricted to European institutions. Moreover, a scale-down due to the 2007-08 financial crises would imply, ceteris paribus, that, after the post-crisis recovery, the banks would resume their operations' levels in markets where they slowed their activities down, which does not seem to be the case in Brazil. Besides, it is important to clearly separate the deleveraging phenomena of financial institutions from a possible deglobalization wave and, particularly, from a structural competitive weakness in a particular market - as assessed in this paper.

Claessens and Van Horen (2015) made the more prominent quantitative analysis regarding factors associated with the foreign-banks exit panorama in diverse economies. The most expressive

12 According to the Banking Economy Report (BCB, 2017), foreign banks are the group that presented the lowest Return Over Equity (ROE) indicator, for instance, in 2017 - at 11\%, while domestic players (public and private) showed ROE levels above $14 \%$ in the same year. Mettenheim (2010) presents data for a ROA indicator in the same direction. 
results of their model show the relevance of the occurrence of financial crises - in the home country and/or in their countries of entry - in the foreign banks decision to stay or leave. They also found significance for the variable associated to the longevity of the institution in the country and to the one that indicates its market share upon exit, both in the negative direction. ${ }^{13 .}$

It should be noted, however, that although the model of Claessens and Van Horen is based on a robust sample ${ }^{14}$ of emerging countries and OECD member countries, there is no detailed discussion of particular cases (as appears to be the Brazilian one) nor further detailing of the transmission channels through which the suggested factors would effectively impact the banking competitive landscape.

An attempt to advance in this debate can be organized around three central poles:

(i) the discussion of characteristics and structural elements of the sector in addition to legal and institutional arrangements that may be relevant in the understanding of the foreign bank presence dynamic;

(ii) the role and the influence of state-owned banks in the concentration and organization dynamics of the sector; ${ }^{15}$ and

(iii) the individual and/or organized behavior of the private players of the sector, in particular with regard to possible endogenous protection strategies by them - both in businessstrategic and political-institutional terms.

As evidences on these three poles have significant differences on their nature, they are analyzed separately, as it follows.

\subsection{Market structure and institutional arrangement: competitiveness, organization and the accommodation of foreign players}

The market structure of the Brazilian banking sector is recurrently classified in variations of an oligopolistic competition, with high concentration levels and the presence of scale and scope

13 See Table 03 - Factors Associated with Changes in Foreign Bank Presence, Claessens and Van Horen (2014). While the occurrence of crises is positively associated with exit decisions by banks, the time of their presence and their market share are negatively associated.

14 The total observations assessed by the authors range from 1,129 to 1,221 financial institutions, covering countries from all continents and of different income levels.

15 Among the main Brazilian public banks, this work generally refers, to a large extent, to Banco do Brasil and Caixa Econômica Federal - commercial banks - and, to a lesser extent, to the National Bank for Social Development (BNDES), a development bank. Particular cases are indicated individually. 
economies (PAULA, OREIRO, BASILIO, 2013; TABAK, GOMES, MEDEIROS, 2015). These characteristics can be confirmed by the gradual reduction of the number of banks over the last two decades, totaling 94 in 2018 (vis-à-vis 129 in 2000), and by the progressive increase in the market share of the largest players. ${ }^{16}$ Since 2008 , the market has been largely dominated by private banks Itaú Unibanco (Itaú) and Bradesco, state-owned banks Banco do Brasil $(B B)$ and Caixa Econômica Federal (CEF), and the Spanish Santander Brasil (Santander). Together, they accounted for 81.2\% of the country's total banking assets in 2018.

Table 1 - Market share top 5 banks in terms of total assets, $2018{ }^{17}$

\begin{tabular}{llr} 
Bank & Ownership & Market Share \\
\hline Itaú & Private & $19.9 \%$ \\
Banco do Brasil & State-owned & $18.9 \%$ \\
Caixa Econômica Federal & State-owned & $16.8 \%$ \\
Bradesco & Private & $15.1 \%$ \\
Santander & Private & $10.5 \%$ \\
\hline
\end{tabular}

Source: BCB, calculation by the author

Although a theoretical study and empirical evaluation of oligopolistic market structures and their application to the Brazilian case are not the object of this study, it is worth mentioning, among the theoretical and competitive characterizations found in the literature for the Brazilian banking sector, that the typology of Labini (1969), also described by Possas (1990) from a Neoschumpeterian perspective, ${ }^{18}$ of differentiated-concentrated oligopoly, seems especially adequate for its characterization (as also argued by Lima, 2008).

According to this concept, this market category would combine elements of a differentiated oligopoly, in which consumers exercise distinct consumption preferences (ultimately related to subjective factors), with elements of a concentrated oligopoly, in which there is high concentration among few players and, at first, price competition is not considered a "regular procedure"

\footnotetext{
$16 \quad$ BCB, 2018.

BNDES, which would occupy the fifth position in the ranking among the largest assets of the Brazilian financial system in 2018, was not considered in this sample.

18 Although this research did not intend to enter into theoretical reflections on the most appropriate framework for the firm theories` discussion that are inevitably associated with the analysis of the market structure of the banking sector in Brazil, it should be noted that the neoschumpeterian perspective seems, due to its focus on the players' competitive behaviors, the most fit for the proposed debate, as it is essentially associated with the accommodation of foreign entrants by domestic competitors in competitive terms.
} 
(POSSAS, 1990). ${ }^{19}$ Such a characterization can be sustained for the case of the Brazilian banking industry without much controversy, and although its discussion is not exactly the focus of this work, it is supported by the elements discussed in the sequence of this session.

In order to study the concentration in the banking sector in Brazil, the Concentration Ratio (CRk) index (plotted in Chart 2) and the Herfindahl-Hirchman (HH) index (plotted in Chart 3) were calculated and crossed with the participation of foreign players over time. Both are recurrent indicators in the antitrust microeconomic literature and are commonly used by regulators in concentration assessments.

The CRk was calculated as follows:

$$
C R_{k}=\sum_{i=1}^{k} S_{i}
$$

Where $k$ is the total of the selected banks - calculated in this work for a sample of five institutions, in line with the standards used by the BCB on its recent reports - and $S i$ is the market share of each bank $i$, in turn measured based on their total assets, according to data by the BCB. In Chart 2, the total number of banks ${ }^{20}$ present in the financial system in the period was also plotted.

19 It should be noted, with regards to this particular point, that interviews with foreign bank executives operating in the Brazilian market conducted by Carvalho and Vidotto (2007) indicated that price competition was not in fact a strategy considered central to these institutions during the period studied by the authors.

20 The institutions assessed were the ones classified by BCB as "Commercial Bank, Multiple Bank with Commercial Certificates or Savings Bank (CEF)", which in 2018 represented 83.13\% of the assets of the Brazilian financial system. 
Chart 3- $\mathrm{CR}_{\mathrm{k}} 5$ Index, Total Banks and Foreign Banks Market Share, 2000-2018

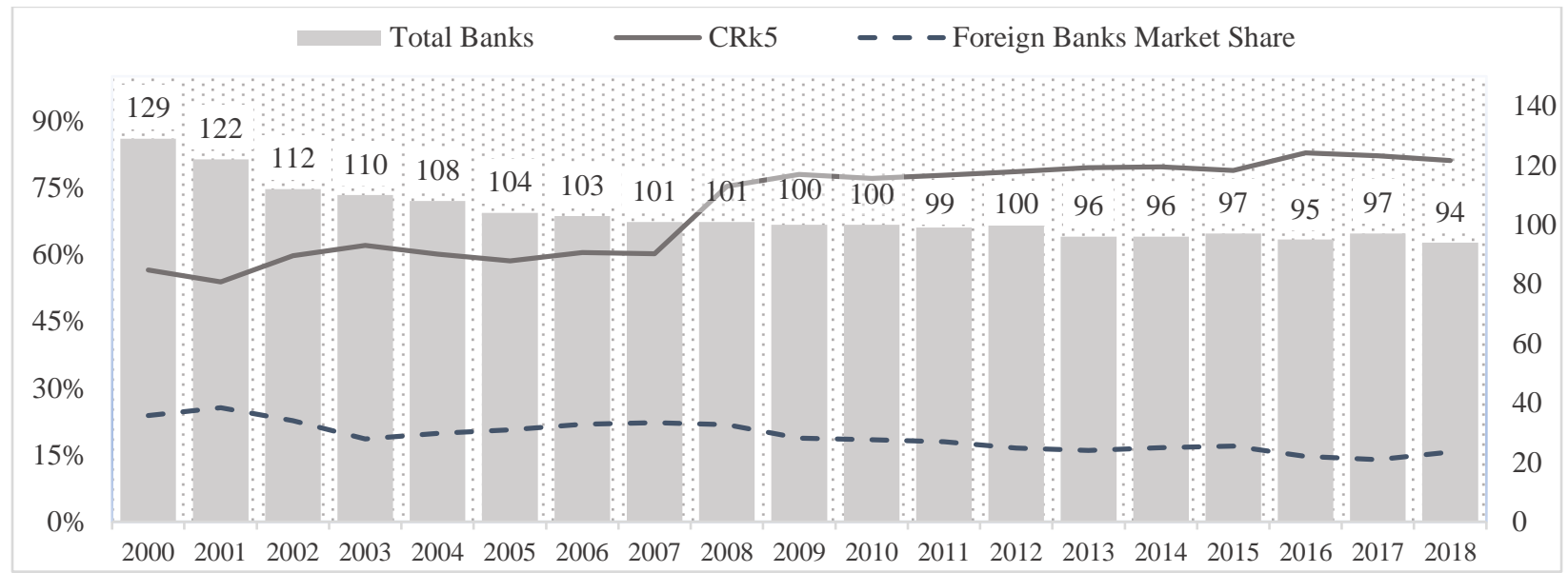

Source: BCB, calculated by the author

In addition to the gradual growth of CRk5 (particularly after 2007), there is a significant and consistent correlation between this trend and the negative evolution of the market share of foreign players - in $86.7 \%$ for the entire period for the two variables.

Considering that such a relation can (and perhaps tends to), theoretically, have simultaneous causality, it is possible to discuss the existence of an isolated (though difficult to measure) effect by the high concentration of the sector in the attraction/permanence of foreign players in the domestic market, as it follows. It should also be noted that Santander, a Spanish bank, has been making it to the top five of the ranking (thus composing the CRk5 indicator) since 2008, which reinforces considerably this hypothesis, as an increase of its relevance, ceteris paribus, would tend to indicate an increase in the relevance of foreign banks as a whole, which does not happen ${ }^{21}$.

This relationship between concentration and foreign participation is also indicated - and perhaps visually better evidenced - when the market share of foreign banks is plotted versus the $\mathrm{HH}$ index, which is calculated as follows.

$$
H H I=\sum_{i=1}^{n} S_{i}{ }^{2}
$$

21 Although ABN Amro, whose fifth position in the ranking of largest assets is taken by Santander 2008, is also a foreign bank, in previous years the position was occupied by Unibanco, Brazilian, ensuring the consistency of the argument. 
Where $n$ is the number of total banks and $S i$ is the market share of each bank $i$, again measured on the terms of their total assets.

\section{Chart 4 - HH Index vs Foreign Bank Market Share, 2000-2018}

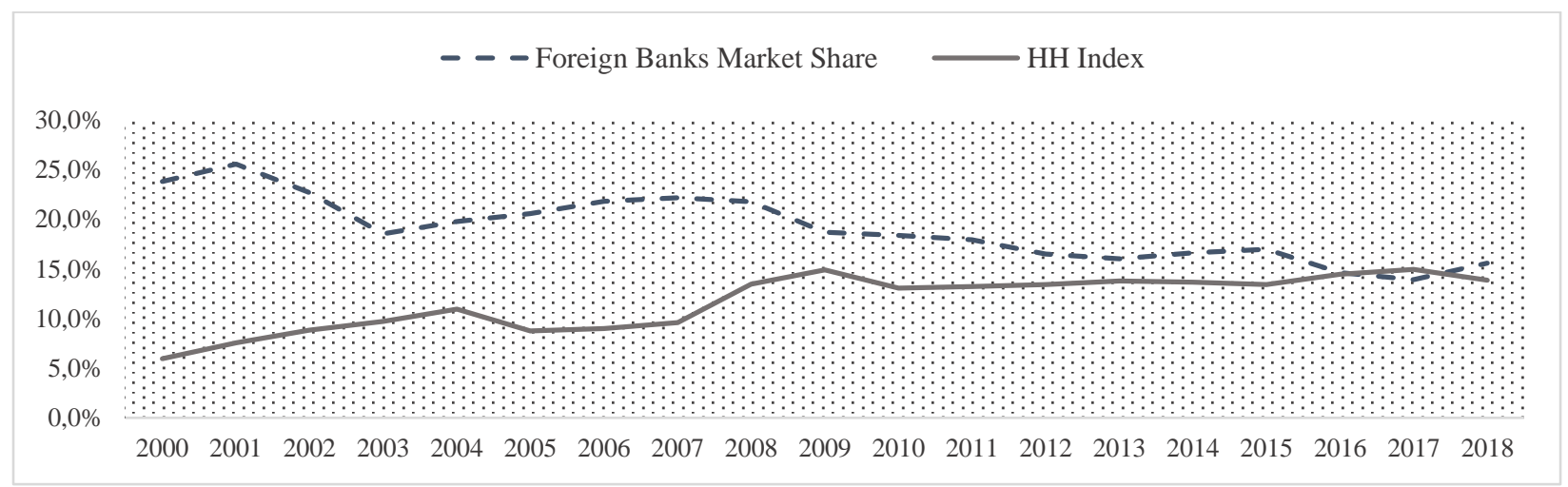

Source: BCB, calculation by the author

For the two variables, the correlation over the period is calculated at $84.4 \%$.

Given the likely bilateral causation of the two trends (considering that the increase in concentration over the past two decades is mostly due to the increase of the major domestic banks' market shares), it would not be accurate, within the non-quantitative scope of this paper, to characterize the sector's high concentration per se as a dominant driver of the decreasing relevance of the foreign banks - at least not by analyzing only the identified correlation. However, it is possible to discuss the implications of this hypothesis from the analysis of indirect elements - or, in other words, to assess its consistency based on other aspects of the banking sector's structure that may relate to its concentration level.

In this sense, the implication of the market's high concentration on the players' strategic behavior - and this on foreign banks' capacity to compete in the market - is an example. Tabak, Gomes and Medeiros (2015) argue that firms in the industry with higher market powers have a wider range of strategic possibilities that provide them with more flexible risk $\mathrm{x}$ return portfolio combinations. This implicates that banks with smaller market power, such as most of the foreign banks in the market, have a more limited competitive scope, possibly becoming exposed to risk $\mathrm{x}$ return strategies less advantageous than the ones practiced by their bigger competitors.

Another important structural point along the same lines, which was shown by Barbosa, Rocha and Salazar (2013), is the thesis that conglomerates exert substantial superiority in market 
power vis-à-vis their competitors with more limited operations ${ }^{22 .}$ The implication of this in terms of competitive barriers for foreign players in the sector is clear, since most of the ones present in the Brazilian market tend to focus on operations of limited scope. These are, for example, the cases of JP Morgan Chase, BNP Paribas, Morgan Stanley and Credit Suisse, among others, which have relevant market shares in other countries, but in Brazil operate essentially and almost exclusively as banks of investment, with none of them making even to top 15 in the ranking of the country's largest assets in $2018 .^{23 .}$

Speaking of the importance of scope economies, it should be also reinforced that scale and capillarity - including in physical terms, considering the quantity and capillarity of the branches of each bank - are a fundamental factor in the understanding of the Brazilian banking sector competitive structure (ARAUJO \& MENDES, 2018). ${ }^{24}$ One evidence of this is the direct relationship between the banks total branches and their market share: in 2018, while the participation of foreign banks in the total assets of the sector was $15.6 \%$, its participation in the total of branches was $14.2 \%$.

Table 2 - Market and Branches Share per Bank Ownership, 2018

\begin{tabular}{lrr} 
Ownership & Market Share & Branches Share \\
\hline Public & $41.1 \%$ & $42.8 \%$ \\
Private & $43.2 \%$ & $43.0 \%$ \\
Foreign & $15.6 \%$ & $14.2 \%$ \\
\hline \hline
\end{tabular}

Source: BCB, author's calculation

Comparing total assets by the number of agencies, a significant result is obtained indicating the importance of this capillarity: while domestic banks currently concentrate BRL 404.00 on assets in every 1.000 branches, foreigners concentrate BRL 451.00 , or $11.77 \%$ more. $^{25}$. While this may be seen as an indicator of relatively higher efficiency in favor of foreign banks, it is also a strong indication, given the consistent superiority of domestic banks in market share historically, that capillarity is in fact an important mechanism through which players may have increased their holdings in absolute terms in the market over time.

22 Institutions considered as conglomerates are the multiple banks that offer a broader portfolio of products and services in comparison with those that only offer basic products, such as credit cards and personal loans.

$23 \quad$ BCB, 2018.

24 In their econometric model, Araújo and Mendes (2018) found a positive impact of branch capillarity as a variable with a significant impact on bank profitability between 2010 and 2015.

$25 \quad \mathrm{BCB}$, calculation by the author. 
It should also be highlighted the fact that Brazil is a heterogeneous country in demographic and geographic terms, with highly unequal indexes of financial inclusion, reinforcing, in practical terms, the importance of physical service points in the sector's competitive dynamics (despite its decreasing importance over the past decade due to the growing adoption of the internet banking). ${ }^{26 .}$ For the purposes of this study, financial inclusion is assessed by the analysis of the Financial Citizenship Index (ICF) ${ }^{27}$, calculated by the Central Bank of Brazil, as indicated in Table 3:

Table 3 - ICF per State

\begin{tabular}{ccccccccc}
$\mathbf{0 - 1 0}$ & $\mathbf{1 1 - 2 0}$ & $\mathbf{2 1 - 3 0}$ & $\mathbf{3 1 - 4 0}$ & $\mathbf{4 1 - 5 0}$ & $\mathbf{5 1 - 6 0}$ & $\mathbf{6 1 - 7 0}$ & $\mathbf{7 1 - 8 0}$ & $\mathbf{8 0 +}$ \\
\hline PA & AP & CE & SE & MT & MS & RS & SP & DF \\
& MA & BA & RO & GO & ES & SC & & \\
& AM & RR & RN & & MG & PR & & \\
& TO & PB & & & RJ & & \\
& AL & PE & & & & & \\
& AC & & & & & & \\
& PI & & & & & \\
& & &
\end{tabular}

Source: BCB Financial Citizenship Report 2018

The high discrepancy between the states' levels of financial inclusion (for instance, while the Federal District presented an 87.2 ICF in 2018, Pará presented 7.7) reinforces the importance of capillarity in terms of physical presence (ultimately indicated by each bank's number of branches) in the Brazilian banking sector, as the population of regions with lower levels of financial inclusion tend to depend substantially more on direct and personal banking relationships in order to access banking services. This has ultimately undermined the competitiveness of foreign banks, as their domestic competitors have always had a substantially higher structure of branches in all regions of the country in comparison with their foreign competitors, as shown in Chart 4:

26 According to Silva (2006), in 2005, Brazil was only second to the United States in number of ATMs in the world, which reinstates how important brick and mortar banking agencies are in the Brazilian context. Also, after 2014 the total amount of agencies in the Brazilian market started a process of gradual decline (up until that year, it had been increasing), following the international trend of other customer services being more widely used.

27 Financial Education Indicator (ICF) is calculated by BCB based on 13 markers, nine of which describe financial inclusion; the remaining four measure how knowledgeable the population is on finances. 
Chart 5 - Total branches per bank ownership, 2000-2018

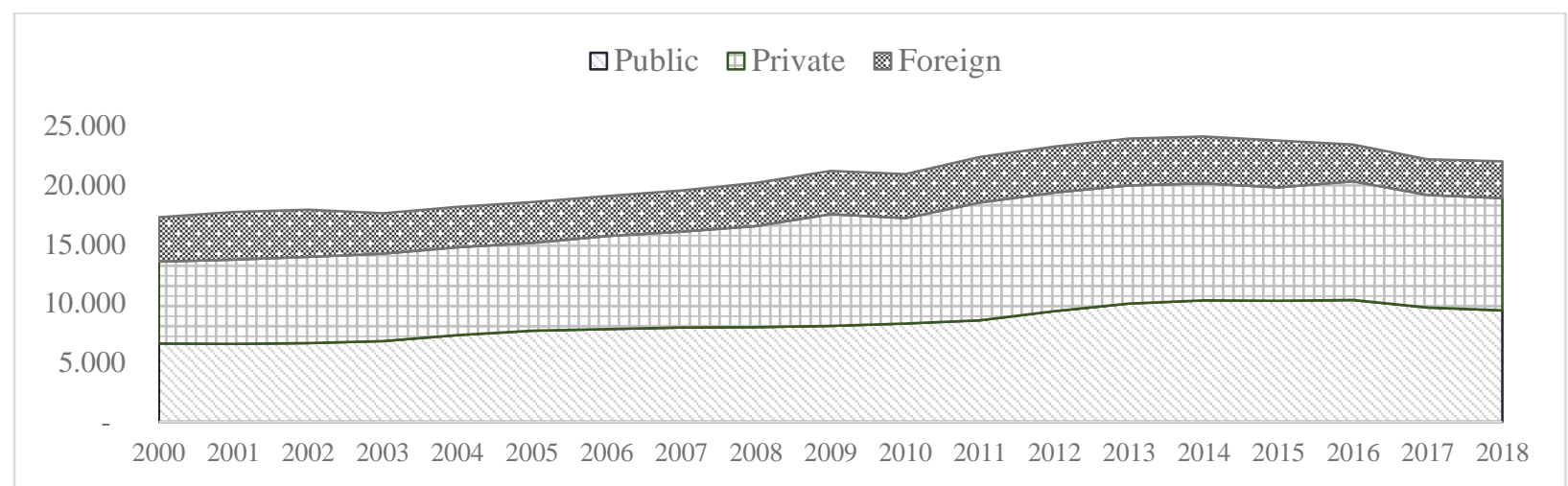

Source: BCB, calculation by the author

As suggested by Possas (1998), subjective aspects should also be discussed in competitive dynamics' analysis, particularly as they seem to be especially important in sectors whose products and services are subject to notorious intangibility, such as the financial one. According to this author, there are two types of elements that should be particularly discussed: knowledge and reputation. While the former is considered essential on the firms' productive processes and productivity levels, the second relates directly "to the circulation of goods, reducing transaction costs and/or stimulating the choice of a particular producer" (POSSAS, 1998, p. 99).

In the case of the Brazilian banking market, even though there are not many works aimed at discussing directly these elements (to the best of this author's knowledge), they are important aspects in the discussion of foreign banks' competitiveness. According to Claessens et al. (2001), for example, the asymmetry between the quality of market information by domestic and foreign financial players is an important factor in the sector's risks balancing, representing a direct competitive disadvantage for the second group.

In the same sense - and in a broader perspective - the literature presents strong evidences towards the role of connections and local political information of the companies in the appreciation of their assets (BANDEIRA-DE-MELLO et al, 2001; FACCIO, 2006; CLAESSENS; FEIJEN; LAEVEN, 2008), thus also configuring structural weaknesses for foreign players. It is worth mentioning, illustratively, the expressive and recurrent connection between representatives of regulatory institutions and companies from the private sector in the banking sector. Since 1985 , 
for example, at least 10 out of the total 19 governors of the Brazilian Central Bank came immediately from private financial institutions in Brazil. Although this does not necessarily imply the exercise of political influence of these companies in BCB's policies, it is, a priori, an indication of potential informational advantages for the domestic banks, as only one out of all these 19 came from a foreign bank.

In terms of reputation, the dimension that seems most adequate for the understanding of the competitive dynamics of foreign banks, according to the literature, seems to be the one that deals with the level of robustness of the relationship of these players with their clients. On the same token, it is worth discussing the work of Berger et al. (2005), who show that foreign banks tend to have more fragile relationships with their clients than domestic banks in local markets. This is indicated by the authors' finding that, in general, companies that have a foreign bank as their main provider of financial services tend to have more financial ties with other institutions (other banks as supporters) than those that focus their financial activity on domestic banks. ${ }^{28}$

In this sense, it is also fair to imply that the wider capillarity by domestic banks (given its higher branch networks, as previously discussed) in the Brazilian case has also provided them with reputational advantages vis-à-vis their foreign competitors, as the wider presence of direct representatives countrywide - particularly in smaller cities - ultimately mean that they have better brand positioning than their foreign competitors, whose reach (in terms of direct personnel contact) has been substantially more limited over the past decades.

Another element indicative of the reputation challenges for foreign competitors', particularly in the Brazilian case and that reinforces Gomes, Oliveira and Matias (2017) argument about the higher funding costs faced by foreign banks in the country, is that brought by Carvalho and Vidotto (2007). These authors reported, from interviews with executives of some of the foreign banks operating in Brazil, the difficulties in recruiting professionals from domestic banks to the formation of teams with local market knowledge. Although this may be related to a broader set of factors, it is reasonable to consider that the notorious reputation and prestige of domestic banks poses a not negligible obstacle to their foreign competitors in this regard.

28 Over the course of this research, the data collected has not brought up any studies on analysis of this phenomenon when it specifically affected the Brazilian market; however, this hypothesis is pertinent to the trajectory of market share observed and discussed throughout this work. 
Moreover, the potential importance of the banks' relationship with the Brazilian government is also worth discussing. Anecdotally, the controversial case centered on Santander in 2014 illustrates a direct influence of the relationship between the bank and the government on the former's operations, in reputational terms, as widely reported by the press in the following months. What happened was that one of the bank's analysts was dismissed after expressing, in a report for clients, her pessimism regarding the economic policies by the Workers' Party (PT) administration (2003-16) at that time..$^{29}$

In general terms, a close relationship between members of the banking sector and government representatives, particular on the federal level, is also identified as a relevant element on this discussion - even if presenting only indirect effects, in principle. Because it is mainly played by private players, the dynamics of this are dealt with in depth in session 4.3. Nevertheless, it is worthy anticipating that the lack of clear evidences on pro-active and/or significant behaviors by foreign banks towards their relationship with the government has likely played a role on their competitive difficulties in the Brazilian market.

In legal and institutional terms, it is worth taking into account the theses of authors such as Gallager and Prates (2015), who identify the presence of "unique institutional arrangements" (p.23) in the Brazilian financial system. This makes the analysis of its internationalization dependent on specific considerations, as it follows.

They highlight, for example, the sui generis existence and influence in the Brazilian banking sector of the Tax Over Financial Operations (IOF), the National Monetary Council $(\mathrm{CMN})$, the BNDES - and, in a broader perspective, the permanent clash between opposing political and business views of society with respect to commercial opening initiatives. Although there are not direct evidence of these elements impacting directly the foreign bank competitiveness in the Brazilian banking market, the simple particularity of such institutional aspects can be

29 At the time, there was a heated debate, culminating in the employee's being fired, following the former president Lula da Silva's public remarks criticizing her report, which had been made available to the bank's clients. She was later compensated by Santander after filing a lawsuit against the bank. Sources: Juíza manda indenizar demitida por texto contra Dilma. G1, online, Sept 2015. Available at: http://g1.globo.com/economia/noticia/2015/09/juiza-manda-santander-indenizar-demitida-por-texto-contra-

dilma.html Last access: 27 Aug 2019; Justiça mantém indenização de analista demitida por prever crise com Dilma. UOL Economia, online, Feb 2016. Available at: https://economia.uol.com.br/noticias/redacao/2016/02/05/justicamantem-indenizacao-de-analista-demitida-por-prever-crise-com-dilma.htm Last access: 27 Aug 2019 
considered as challenging for new players - particularly the ones that do not count with in-depth knowledge of the country's historic institutional dynamics, such as some of the foreigners. ${ }^{30}$

Regarding these authors' latter point, it is also worth remembering that international trade, which is notoriously low in the Brazilian case, is a significant variable in the model of Claessens and Van Horen (2015) in explaining the phenomenon of foreign bank exit - which, combined with the follow-the-money hypothesis discussed in section 2, stands as a relevant point in this work's discussion. After all, if the country's trade is low and, at the same time, multinational banks enter new markets partially because they want to follow the business of their clients, it makes sense that, ceteris paribus, the presence of foreign players in the Brazilian banking market is low because, to some extent, of the country's low trade levels. In 2016, international trade accounted for only $18.3 \%$ of the country`s GDP, vis-à-vis middle-income countries`average at $38.6 \%$ and more protected countries like India at 27.5\% (NASSIF, CASTILHO, 2018).

Prates and Paula (2013) also highlight the particularly high autonomy levels by the Brazilian economic and monetary authorities, who have access to institutional tools to promote a broad scope of policies without the need of legislative approval, potentially undermining the predictability of the sector - in turn considered an essential variable in foreign investment decisions (DAUDE; STEIN, 2007). An example of this would be the practice, pointed out by Mesquita (2017), by the Dilma Rousseff administration (2011-2016) of "successive changes in the rules for foreign capital flows" (2017, p. 3), which, in addition to impacting the levels of predictability of the sector, would have affected directly the attractiveness of the country to these players $^{31}$.

Alone, such particularities would already be relevant elements in the decision of the foreign players decision to entry/stay in the sector, as discussed. However, there are also more direct institutional aspects that are important to understand this dynamic, especially the fact that the entry

30 IOF (meaning Taxation on Financial Operations) is charged from individuals and companies that perform any credit, exchange, insurance, asset or real estate operations (SUBSECRETARIA DE TRIBUTAÇÃO E CONTENCIOSO, 2015). CMN is the "superior agency of the National Finance System and is responsible for formulating currency and credit policies in the country" (translation by the author. MINISTÉRIO DA FAZENDA, undated).

31 Even though official reasons for the measures taken at the time were, to some degree, imprecise when it came to their main focus, it bears noting that such changes were first and foremost directed to an agenda of insulating the country from effects of the international crises, with direct and indirect action on the exchange rate and volatility of entry/exit of foreign capitals. 
of foreign institutions in the country depends on the direct authorization of the president of the country, who has to publish decrees in favor of (or against) each foreign institution's entry.

According to article 192 of the 1988 Federal Constitution, in its original version, the activity of foreign banks in the country is subject to an assessment on the terms of "national interests", as it follows:

Art. 192. O sistema financeiro nacional, estruturado de forma a promover o desenvolvimento equilibrado do País e a servir aos interesses da coletividade, será regulado em lei complementar, que disporá, inclusive, sobre:

$[\ldots]$

III - as condições para a participação do capital estrangeiro nas instituições a que se referem os incisos anteriores, tendo em vista, especialmente:

a) os interesses nacionais;

b) os acordos internacionais;

(Constituição Federal de 1988, art. 192)

Although Constitutional Amendment n. 40 (2003) revoked the clauses of article 192 (including III, but incorporating it in its caput), no substitute regulation was identified regarding the authorization of the entry of foreign institutions in the country, which remains dependent on individual approval by the president. ${ }^{32} 33$

On this, Ianoni (2010) discusses the non-decision hypothesis, according to which the reasons why there has never have been regulation for this point is due to the lack of interest of the agents with greater power resources (namely the government and domestic banks) on promoting changes on it. It is, therefore, a clear indicator of a legal and institutional barrier in the Brazilian banking market for foreign players, even if, eventually, their entry requests get approved.

Illustratively, a report by local newspaper Valor Econômico (on November 4, 2013), attributed to the then-President Dilma Rousseff's "overly detail-focused style" the fact that his government had dragged, in some cases for more than two years, the authorization procedures for

32 The new text adds point III in its header, as follows: "The national finance system, built so as to promote a balanced development for the country and to serve the interests of the community, in all parts that make it up, including credit unions, will be regulated by complementary laws that will also define the participation of foreign capital in the institutions that take part in it." (text from Emenda Constitucional $n^{\circ} 40,2003$. Translation by the author)

$34 \quad$ It is also worth mentioning the "Exposição de Motivos 311", a measure taken by the Fernando Henrique Cardoso administration, which attempted to, at the time of PROER and PROES, attract foreign banks to the Brazilian bank market by softening entry regulations on the grounds of this being a national interest. The measure, however, "did not make the case for a broad and general opening in the banking sector, but rather for an increase in foreign capital shares based on a collection of expected contributions" (translation by the author). 
the entry of foreign banks into the national financial system during her administration. ${ }^{34} 35$ The Swiss bank UBS, for example, waited 29 months to have its request approved, while the English brokerage Actis waited 28 months, and the German group CHG Meridian, 27 months to have their authorization decrees published after their declarations of purpose of entering the country, all between 2010 and 2013.

On January 3, 2019, then Central Bank Governor Ilan Goldfajn announced that the BCB was developing a regulatory change to streamline the entry process of foreign players by proposing adjustments directly on that point of legislation. Although on the occasion he said that he believed that the measure in itself "would not make a major difference" in the phenomenon of the exit of foreign banks, disregarding its importance, the point was ultimately addressed and included as part of an agenda to promote the competitiveness of the sector developed by institution during his tenure, indicating its ultimate relevance on the competitiveness of the country's banking landscape. ${ }^{36 .}$

\subsection{Public Banks: after crisis`role and impact over foreign-banks competition}

Martins, Bortoluzzo and Lazzarini (2014) point out that "the importance of the [Brazilian] public banks can be expressed both by their representativeness and by their influence on the banking market" (2014, p. 3). These institutions are historically relevant in the country's financial system, and their role in the 2007-2009 financial crisis was notoriously decisive in the set of countercyclical policies of the Brazilian government to cope with the global recession.

As shown in Chart 5, as of 2009, public banks took the lead in the country's credit supply, surpassing national private banks and distancing themselves even further from the level offered by foreign institutions, in turn much lower historically. According to Coleman (2014), this strategy proved to be successful in that it helped reduce the potential of the country's economic recession without generating optimization problems in the allocation of capital at that time.

34 RIBEIRO, Alex. Estrangeiro tem fila para entrar no país. Valor Econômico, online. 2013. Available at: https://www.valor.com.br/financas/3326156/estrangeiro-tem-fila-para-entrar-no-pais. Last access: 27 Aug 2019

35 On March 25 of the same year, Valor Econômico published a statement by the then Banco Central director, saying that at that time 19 foreign banking institutions were waiting for approval on their Brazilian market entry applications. RIBEIRO, Alex. Estrangeiro tem fila para entrar no país. Valor Econômico, online. 2013. Available at: https://www.valor.com.br/financas/3326156/estrangeiro-tem-fila-para-entrar-no-pais. Last access: 27 Aug 2019

36 According to Goldfajn, the main reason why foreign shares had decreased in the country would be mostly related to the scale down hypothesis, discussed in section 4. Although he explains his reasoning based on "the demands of capitalization made by regulators around the world", he does not go into further detail on the general phenomenon (RIBEIRO; SALES, 2017). 
Chart 6 - Distribution of Loans per Bank Ownership, 2000-2018

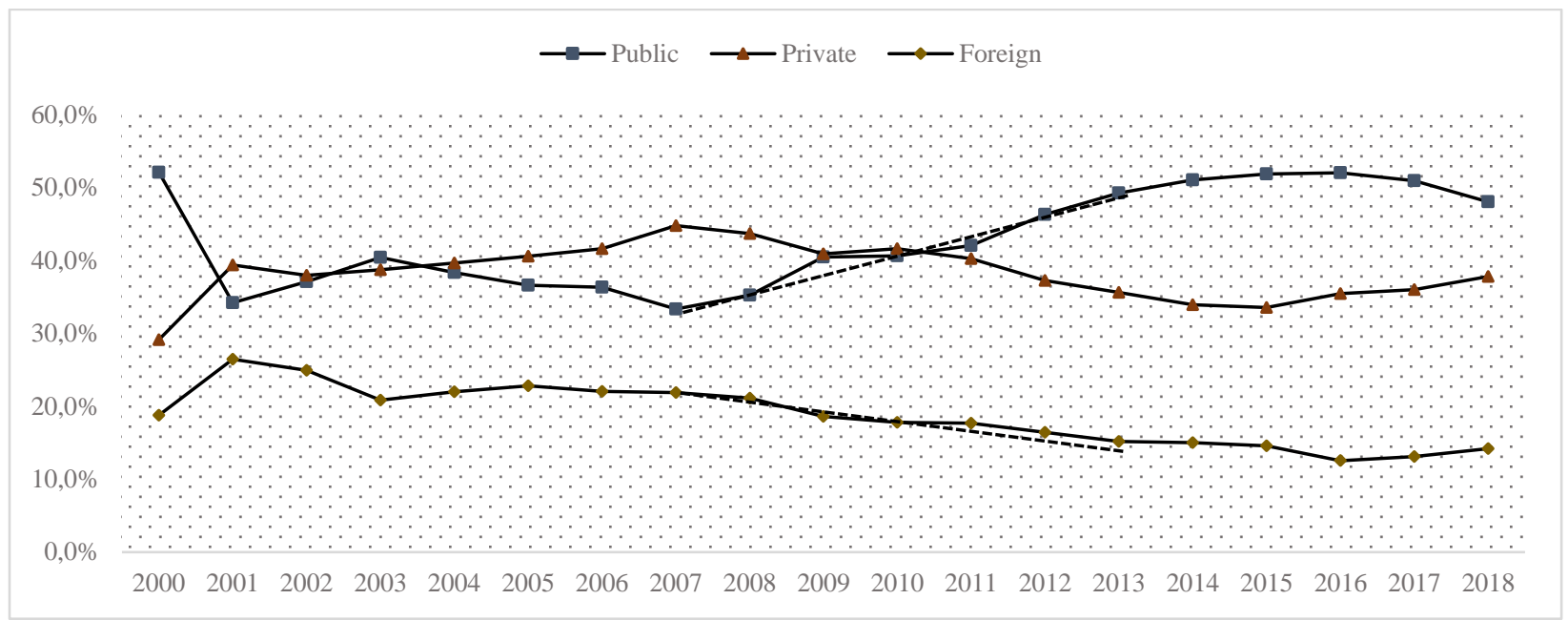

Source: BCB, calculated by the author

This scenario, which marked the country's banking market until at least 2015, is controversial and debatable, as other authors also argue. For Martins et al. (2014), the literature is not clear on the effects of public banks' prominent roles on the levels of competitiveness of banking systems. In the sense of the non-desirability of such a presence, in fact, the authors point out that studies such as those by Bischell (2006) and Coelho, Mello \& Resende (2011) indicate that such behavior seems to be more negative than positive in terms of financial competition. ${ }^{37 .}$

Furthermore, there is a recurrent discussion in Brazil around the crowding out effect thesis, which states that, instead of promoting the credit market as normally expected (particularly in the long term), a hypertrophied role by the public banks may have net aggregate negative effect in this sense (ALMEIDA; LIMA-DE-OLIVEIRA; SCHNEIDER, 2014; LISBOA; LATIF, 2013). ${ }^{38 .}$ These economists suggest that the over-presence of state-owned financial institutions in the banking market inhibits the development of the long-term private credit market as private players choose to position themselves in other niches in the industry rather than competing directly with public banks.

37 While Bischell (2006) dealt with the issue based on the mortgage data collected in Switzerland, Coelho et al. (2013) used Brazilian data to assess whether there is a difference between state-owned and private banks in duopolies, reaching the conclusion that there are not.

$38 \quad$ Almeida et al. (2013) point to state-owned banks' actions in the early 2010s being relevant, especially BNDES': according to their data, loans granted by this institution were so expressive that in 2011 they surpassed those granted by international institutions such as the BID and even the World Bank. 
This thesis is countered by authors such as Mettenheim (2010), who states that the strong presence of federal banks in Brazil has contributed positively to the development of new markets and new services in the banking segment of the country. According to him, these institutions were responsible for unprecedented movements of development of financial products in Brazil - in addition to having simultaneously led to the modernization of the regulation of the sector ${ }^{39} 40$.

However, in addition to the importance of highlighting that such a discussion seems to lack further studies in the literature - in spite of isolated works such as that of Torres (2016), which is robust in favor of the prevalence of the crowding out thesis in the Brazilian market -, the works in defense of the role of the state-owned banks do not show gains in the competitiveness of the sector; contrarily, as in the case of the cited authors, the benefits pointed out in part of them would be in spite of the unwanted effects in the concentration of the market and in the possible repealing of the foreign competition.

In this sense, it should be noted that the correlation between the market share variation of the public banks and foreign banks has been historically high. During the post-crisis period, between 2007 and 2013, in particular, the increase in the dominance of public banks corresponds to virtually all the reduction of the participation of the foreign players, with the market share of the domestic private ones remaining relatively stable during the five years that followed, as indicated by table 3 :

Table 4 - After Crisis Market Share per Ownership, 2007-2013

\begin{tabular}{lrrrrrrr} 
Ownership / Year & $\mathbf{2 0 0 7}$ & $\mathbf{2 0 0 8}$ & $\mathbf{2 0 0 9}$ & $\mathbf{2 0 1 0}$ & $\mathbf{2 0 1 1}$ & $\mathbf{2 0 1 2}$ & $\mathbf{2 0 1 3}$ \\
\hline Public & $36,4 \%$ & $36,6 \%$ & $41,0 \%$ & $40,5 \%$ & $41,6 \%$ & $43,4 \%$ & $45,3 \%$ \\
Private & $41,3 \%$ & $41,6 \%$ & $40,3 \%$ & $41,1 \%$ & $40,4 \%$ & $40,0 \%$ & $38,6 \%$ \\
Foreign & $22,2 \%$ & $21,8 \%$ & $18,7 \%$ & $18,4 \%$ & $18,0 \%$ & $16,5 \%$ & $16,0 \%$ \\
\hline
\end{tabular}

Source: BCB, calculated by the author

While it is reasonable to assume that the expansion - explicitly advocated as a central part of the federal government's economic policy at the time ${ }^{41}-$ of the magnitude of state-owned

39 This author also defends that state-owned banks' actions have served as a means to "help bring Brazil out of underdevelopment, military rule and monetary chaos by providing policy option for adjustment, reform and social inclusion" (2010, p. 3).

40 Mazzucato \& Penna (2015) go in the same direction, arguing that, based on the Market Failure Theory (MFT), there are justifying reasons to support countercyclical investment leadership by these institutions. They do not discuss, however, the optimal long-term conduct of state-owned banks in times of economic normalcy.

$41 \quad$ Among other remarks, then Minister of Finance Guido Mantega stated in June 2009: “[...] We've seen that it's important to have strong state-owned banks in times of crises, because they don't get credit restrictions. It's quite 
banking operations during the crisis (and then by the Rousseff Administration in general, as of 2011 and until 2015) has directly affected the panorama of foreign banks, even if a priori no assessments are made regarding the desirability of this in general economic terms, it is important to go further in the detail of this phenomenon: after all, through which transmission channels and to what extent has this materialized?

Data from Paula, Oreiro and Basilio (2013) indicate that, during the financial crisis period, the increase in the market share of public banks was due to the increase in the operations of these institutions particularly in the rural and housing credit segments - with direct relation with the reduction of the participation of the foreigners, historically little active in these sectors. This movement - also observed in the data brought by Oliveira (2018) and indicated by the model developed by Sanches, Junior and Srisuma (2016) - reinforces the relevance of the crowding out thesis, indicating a strong tendency on the part of private banks, in particular foreign banks, not to compete in sectors dominated by Brazilian state-owned banks, particularly in small cities, as will also discussed over the next session.

Mesquita (2017) contributes to this discussion by suggesting that, during the Rousseff administration, the federal government made large-scale use of the public banks as instruments of "para-fiscal policy", as he puts it. According to this author, the expansion of these institutions' financing portfolios had a nature of fiscal expenditure ${ }^{42}$. Although this is a strong argument (and has not been proportionally detailed by the author), this would have provided the market with negative effects as it represented an intervention agenda of low transparency in the sector, among other aspects related to governance and predictability.

Cortes and Paiva (2017), similarly, explore the thesis that an overly large scope of the state-owned banks in the Rousseff administration - added to a considerable change in BCB governance and guidelines starting in 2011 contributed to the deterioration of the credibility of the monetary authority in the country and directly affected the dynamics of the banking market in that period. The indirect effects of this on variables such as inflation and interest rate, therefore, would have reduced the sector's attractiveness for foreign banks.

the opposite, they can add credit and help keep the market going." (MANTEGA, 2009, in a speech at the State-owned Banks and Development Seminar, apud JARDIM, 2013).

$42 \quad$ Mesquita (2017) also highlights that this expansion was possible due to the expressive capitalizations that the state-owned banks went through under the administration. 
Additionally, and based on a political economy perspective, Mettenheim (2010) assesses, by analyzing the agents' behavior and the political structure of the sector, how the liberal theories about privatizations and the political power of private groups explain the paths taken by the banking segment in Brazil. According to this author, public banks in Brazil count with competitive advantages vis-à-vis private banks - and in particular vis-à-vis foreigners - because they have strong historical reputations, greater organizational reach levels and networks that allow them to overcome political challenges and capitalize their initiatives on social forces. Likewise, and by gathering such virtues, the Brazilian case would be an "anomaly to the neo-liberal theory", reinforcing the thesis that the low presence of foreign players in the country, thus, is largely due to the prominent performance of its state competitors. ${ }^{43}$

In terms of the practical mechanisms through which this occurs, data from Oliveira (2016) - detailing the differences in the balance sheet strategies of the five largest Brazilian banks in the past decade - are an indication that state-owned banks have acted, particularly in the period postfinancial crisis, as agenda-setters; that is, players that, in several cases, define the market's behavioral trend from their individual agendas - including, and above all, by taking greater risks in periods of greater uncertainties, such as in the post crisis and during the Rousseff administration, until at least 2015.

This argument is especially relevant if crossed with the thesis by Crystal et al. (2002), which suggests that foreign financial institutions tend to practice a so-called "defensive behavior" in comparison to their domestic competitors, adopting a slower pace in expanding their portfolios and prioritizing more liquid assets in most cases than illiquid ones. The combination of a greater risk-taking tendency in a pioneering way on the part of the public banks added to a more conservative behavior of the foreign banks is, thus, another strong indication in favor of the influence of the first in the low market participation of the last ones, especially in the Brazilian case.

Staub et al. (2010) evaluated the efficiency of the banking market from three categories: technical, cost and allocative. ${ }^{44}$. Their results, also discussed by Freitas (2018), indicate that, in the

43 To Mettenheim (2010), this anomaly is particularly due to the fact that federal banks have always been well capitalized, have been permanently challenged to pursue new strategies and policies, and have offered advantageous alternatives as tools for politics.

$44 \quad$ While technical efficiency means maximum output capacity on input quantity, allocative efficiency refers to optimization of input and output mix in the productive process. Finally, cost efficiency is the product of both allocative and technical efficiencies (Havrylchyk 2006, apud. Freitas 2018). 
period observed, state-owned banks dominated the efficiency indexes of the sector in particular in the category related to their cost structures. This result is contrary to the agency theory hypothesis, which states that state-owned banks tend to be more inefficient than their competitors due to the possible divergence/conflict of interests associated with their governance and their role as inducer of economic development ${ }^{45}$.

It is also worth noting that, among all three categories, foreign banks had the worst results among the three ownership classifications in the period analyzed. According to the authors, this is evidence in favor of the home field advantage hypothesis, discussed by Berger et al. (2000) and that suggests that domestic financial institutions tend to be more efficient "due to organizational diseconomies to operating or monitoring an institution from a distance and also to differences in regulatory and supervisory environment" (p. 207).

It should be noted that such thesis is in line with the points discussed in the previous section, reinforcing the role of institutional and legal dynamics in the country's banking market. The homefield advantage hypothesis opposes the global advantage hypothesis, which is discussed by the same authors and suggests that, thanks to the higher ability of certain institutions to propagate better business and risk management practices globally, they are able to overcome the competitive advantages of players. For Staub et al. (2010), this does not happen in the Brazilian case.

In general, as discussed in this section, the influence of public banks on the competitiveness (and hence on the market share) of foreign banks is mainly due to: (i) their positioning as agendasetters, benefiting from higher returns associated to greater risks in the banking market; (ii) the evidence that private banks - including foreign banks - avoid competing in niches that are dominated by the state-owned ones; and (iii) the state-owned banks historical advantages of scale, reputation and organizational reach, in Mettenheim terms (2010), as factors of objective and subjective differentiation of these in front of foreign players - in line with the competitive aspects discussed in Possas (1998) competitive analysis framework.

\subsection{Private banks: strategic behavior, consolidation and endogenous protection}

46 This result also challenges the findings by Micco et al. (2007) and Barth et al. (2004), which show that state-owned banks in developing countries such as Brazil tend to be less lucrative and have worse cost management in comparison to their private competitors. 
The assessment of the ways in which private banks may have acted to prevent/fight the penetration of foreign competitors in the Brazilian market can be divided into two fronts: (i) one dealing with their business strategic behavior, that is, the way they have strategically positioned themselves in the market in the sense of possibly protecting their dominance from foreign competition; and (ii) one focused on the discussion of institutional and/or political mechanisms possibly used by them in this sense.

With regard to the strategic business elements, the emblematic case of Australia, in the 1990s - where the foreign-bank entry is regarded as a failure (STANDING COMMITTEE OF FINANCE AND PUBLIC ADMINISTRATION, 1991, apud STURM; WILLIAMS, 2004) - can, for exploratory purposes, and given its similarity to the Brazilian case, be used as a benchmark. The Australian market structure is similar to that of the Brazilian market with respect to the high levels of concentration and high dominance of domestic players. According to data by the International Monetary Fund, despite an increase over the past three years, currently foreign banks account for only $12 \%$ of the country's banking assets. (IMF, 2019)

As Sturm \& Williams show, the banking market in this country is dominated by four large domestic banks ("Big Four", "Quadropoly"). These would have constituted deliberate entry barriers for foreign entrants through (i) the conduction of successive M\&A operations, mostly aimed at providing them with scale gains and (ii) increased investments in infrastructure (particularly in new branches) to increase capillarity. This strategy, according to the authors, has been successful in that it has been able to guarantee them higher levels of size and efficiency in relation to foreign entrants, who have never managed to consolidate relevant levels of market share in the country.

In the Brazilian case, there is evidence that the behavior of private banks followed a similar trend. According to Araújo et al. (2007), for instance, Bradesco, Itaú and Unibanco intensified their M\&A initiatives, which had gained momentum in the 1990s, in response to the acquisition of Banco Banespa by Santander in 2000 - which was considered a relevant and successful operation in the sector, reaching USD 3.7 billion. $^{46}$

46 It was after this operation that the Spanish bank ranked fifth in most active institutions in the Brazilian banking market, reaching the same level of private competitors in terms of capilarity and penetration (PAULA 2004, apud. ARAÚJO et al. 2007). 
Lima (2008), in turn, says that a central strategy in the market positioning of private banks after the sector's opening in the 1990s was the consolidation of their strategy as multiple banks, which allowed them to reduce costs and unify administratively their portfolios advantages that are inherent to this type of structure, as discussed in section 4.1. Moreover, a segmentation by client category was also pursued, with the creation of the brands Personnalite ${ }^{47}$, by Itaú, and Prime, by Bradesco - both focused on the high-income segment. Such strategies are particularly important to discuss their competitiveness vis-à-vis foreign entrants as a significant part of the latter's positioning, such as that of HSBC and Citibank, has always been mostly centralized in this same income segment. There was, therefore, a strategic definition of direct competition by the domestic private sector in the niche of foreigners acting in this sense - even if this movement has not been exclusively due to this reason.

Another significant evidence on the relevance of the behavior by private banks as a relevant barrier to the competitiveness of foreign players in the market was the movement carried out by the American conglomerate Bank of America in 2006. Active in the country through its subsidiary Bank Boston (established in Brazil since 1947), the institution sold its retail operation in 2006 to Itaú in exchange for an equity share in the Brazilian bank. That is: Bank of America decided to continue investing in the Brazilian banking market but changed its approach to do it through a domestic vehicle - a bigger and more efficient competitor in the local market. This evidences a view that considers the banking market in Brazil attractive enough to invest, but too competitive to accommodate outside players ${ }^{48}$.

In the case of the acquisition of Citibank by Itaú, which was announced in 2016, another evidence of its attitude towards foreign competition deserves attention: as widely reported by the local press at the time, ${ }^{49}$ the transaction occurred after the notorious interest in the acquisition by

\footnotetext{
$47 \quad$ On that note, the Personnalité brand was created in 1996, when Itaú purchased the French and Brazilian Bank (BFB), which operated servicing the high-class sector.

$48 \quad$ It bears noting that this position ended in 2010, when Bank of America terminated their partnership with Itaú in a movement of capital raising amidst the global economic crisis, as was reported at the time by ALVES, Aluísio. Bank of America sairá do capital do Itaú Unibanco. Revista Exame, online. 2010. Available at: https://exame.abril.com.br/mercados/bank-of-america-saira-capital-itau-unibanco-560971/. Last access: 27 Aug 2019

49 GONZÁLZES, Pablo; LUCCHESI, Cristiane. Santander se prepara para comprar ativos do Citi no país. Revista Exame, online. 2016. Available at: https://exame.abril.com.br/negocios/santander-se-prepara-para-comprarativos-do-citi-no-pais/. Last access: 27 Aug 2019
} 
Santander, who even hired another foreigner, the Swiss Credit Suisse, to advise the bank in the operation. However, with a more aggressive proposal, Itaú ended up closing the deal, valued at BRL 710 million.

Years before, in 2001, the Brazilian bank had carried out a similar move: after disputing with Bradesco and Unibanco, Itaú acquired the asset management branch of the British company Lloyds, which had about 4,000 clients in the country at the time. According to Alfredo Egydio Setúbal, then Executive Vice-President of Capital Markets and one of the controllers of the institution, the operation "shortened the bank's expansion process by two years"; that is, it served as a powerful tool for increasing the bank's scale at the same time in which it eliminated one of its competitors from the market.

On Bradesco's side, there is also clear evidence of the adoption of proactive and aggressive behavior in relation to the competition with foreign players in the Brazilian market in the last two decades. In 2003, the bank acquired the assets portfolio valued at approximately BRL 7 billion from the American JP Morgan, in an operation that, according to the president of the American institution, was due to its difficulty in growing in this segment in Brazil, despite the persistent business interest in the country ${ }^{50}$.

Nevertheless, Bradesco's most relevant operation in terms of magnitude and market impact was certainly that of 2016, with the acquisition of the Brazilian operation of HSBC, which had announced losses of BRL 549 million in 2014 and BRL 735 million in $2015^{51}$. Through the operation, Bradesco increased its assets by $15.9 \%$, its deposit base by $29.7 \%$, its number of branches at $18.9 \%$, and, finally, its customer base by $19.5 \%$.

Itaú desbanca Santander e fica mais perto de levar Citi Brasil. Infomoney, online. 2016. Available at: https://www.infomoney.com.br/mercados/acoes-e-indices/noticia/5558620/itau-desbanca-santander-fica-mais-pertolevar-citi-brasil. Last access: 27 Aug 2019

BRONZATI, Aline; CARVALHO, Renato; SCARAMUZZO, Mônica. Banco Central aprova compra do Citibank pelo Itaú Unibanco. Estadão, online. 2017. Available at: https://economia.estadao.com.br/noticias/negocios,bancocentral-aprova-compra-do-citibank-pelo-itau-unibanco,70002061930. Last access: 27 Aug 2019

50 PORTES, Ivone. JP Morgan reduz atuação no Brasil com venda de carteira ao Bradesco. Folha, online. 2003. Available at: https://www1.folha.uol.com.br/folha/dinheiro/ult91u62620.shtml. Last access: 27 Aug 2019

51 MARQUES, Felipe. HSBC Brasil tem prejuízo 37\% maior em 2015, de R\$ 735,4 milhões. Valor Econômico, online. 2016. Available at: https://www.valor.com.br/financas/4488690/hsbc-brasil-tem-prejuizo-37maior-em-2015-de-r-7354-milhoes. Last access: 27 Aug 2019 
According to local magazine Exame ${ }^{52}$ in 2015 Bradesco's internal sources considered the operation especially emblematic as there would have been a speculative movement in the decade before in the opposite direction of the operation: HSBC was considering acquiring Bradesco, at a time when the banks operations' expansion in the country had reached its highest level. Santander also was interested in the acquisition of HSBC, but its offer did not cover that by the Brazilian bank - considered aggressive enough by the market so that, on the day of the announcement, its shares fell $1.4 \%$ on the Bovespa. According to analysts heard by local newspaper Folha de São Paulo, the total value of the operation, at USD 5.2 billion, was way above the market's expected value, less than USD 4 billion - reinforcing the aggressiveness of the operation.

However, it proved to be successful enough in the long run that in November 2018, Bradesco's CEO Octavio de Lazari stated that "[Bradesco] would buy HSBC again, even if it had to pay more." He further reinforced the strategy's competitive rationale by saying: "If we had not bought it, who would had? Our biggest competitors: Itaú or Santander. ${ }^{53}$ ",

It bears noting, from this statement, the classification made by Bradesco's CEO of the private banks Itaú and Santander as the bank's main competitors - despite state-owned Banco do Brasil and Caixa Econômica Federal having historically outperformed the Spanish bank in market share. Such a consideration reinforces the recurrent thesis that there is a clear definition of niches in which each ownership category of banks present in the country compete (TORRES, 2016).

In the case of Santander, for instance, the data collected from Oliveira (2016) indicate high similarity in several elements of its balance sheet strategy in relation to those exercised by Itaú and Bradesco - as opposed to those practiced by BB and CEF, also analyzed in his work.

According to his data, this occurs in several elements of their balance sheet strategy, such as in the allocation of liabilities, in the levels of inter-bank investments and in the proportion of total deposits over total liabilities, for example. Although foreign banks are impacted by the behavior of the Brazilian public banks in various dimensions, in terms of market positioning they tend to be especially affected by the strategic business behavior of their domestic private peers, who have acted aggressively in terms of market conquest in its niches in the last two decades.

52 Revista impressa: edição 1095, ano 49, no 15, 19/08/2015.

53 MARINHO, Helder; LUCCHESI, Cristiane. Bradesco compraria HSBC de novo mesmo pagando mais, diz Lazari. UOL Economia, online. 2018. Available at: https://economia.uol.com.br/noticias/bloomberg/2018/11/14/bradesco-compraria-hsbc-de-novo-mesmo-pagandomais-diz-lazari.htm. Last access: 27 Aug 2019 
Carvalho and Vidotto (2007) add the existence of a notable rigidity by foreigners in adapting their business strategies briskly over time. According to their sources, the highly bureaucratic dynamic of approving policy adjustments and strategic repositioning by foreign parent companies constitutes a relevant competitive obstacle for these banks, since such operational adjustments tend to become slower and competitors, at least in the Brazilian case. This becomes particularly important when crossed with the relatively high policy unpredictability levels discussed in section 4.1, as recurrent changes in the regulatory/macropolitical environment inevitably require high levels of coordination in order to players not to suffer / take advantage of new regulation paradigms, ultimately hampering the competitiveness of institutions that are slower in making these adjustments, such as the foreign banks.

Regarding the second point discussed in this section, on the political-institutional mechanisms possibly used by private banks competitively to the detriment of their foreign competitors, it is worth considering arguments such as those of Miranda (2003), who assesses the behavior of private banks in the 1990`s by discussing the power of these institutions in the country's political environment. He points out, for example, the frequent and relevant presence of private banks in the list of the largest donors to electoral campaigns in the country, including leftist parties and candidates, such as the cases of the former Presidents Lula da Silva and Dilma Rousseff (Workers' Party - PT).

Table 5 - Largest donors among banks for presidential final campaigns, 2002-2014 ${ }^{54}$

\begin{tabular}{lllr} 
Year & Candidate & Party & 3 largest donors among banks, ranked \\
\hline \multirow{2}{*}{2002} & Lula da Silva & PT & Banespa (D), ABN AMRO Real (F), Santander (F) \\
& José Serra & PSDB & Itaú (D), Bradesco (D), Santander (F) \\
2006 & Lula da Silva & PT & Itaú (D), Bradesco (D), ABN AMRO Real (F) \\
& Geraldo Alckmin & PSDB & Itaú (D), Bradesco (D), ABN AMRO Real (F) \\
2010 & Dilma Rousseff & PT & Bradesco (D), BMG (D), Itaú (D) \\
& José Serra & PSDB & Itaú (D), Bradesco (D), BMG (D) \\
2014 & Dilma Rousseff & PT & Bradesco (D), Safra (D), Itaú (D) \\
& Aécio Neves & PSDB & Bradesco (D), Itaú (D), BTG Pactual (D)
\end{tabular}

54 Some of these donations were made through these banks' subsidiaries - consolidated for simplification purposes. In 2016, donations by private companies were forbidden by the TSE. 
Source: Supreme Electoral Court (TSE) in addition to coverage by local media for missing years ${ }^{55}$ $(D)=$ Domestic Bank; (F) Foreign Bank; PSDB = Brazilian Social Democracy Party

Although the practical effect of such behavior presents measuring complexities given the nature of the lobbying activity (particularly in Brazil, where it is not regulated), the mere fact that domestic private banks have dominated the top positions among donations to the winning presidential electoral campaigns in recent years, while foreign banks have presented timid behaviors in this regard, is already a strong indication of a possible asymmetry in the dynamics of political activity by the players in this market ${ }^{56}$. Moreover, the fact that the period when foreign banks presented the highest level of political engagement (on the terms of electoral donations) was precisely the same when they reached their record high market share levels, in 2001-2002, may also be an indicative of this same trend.

Furthermore, the recurrent practice by Itaú and Bradesco, as indicated in the table, of making expressive donations to both candidates in these elections indicates that, more than supporting a particular political-economic platform, the initiative is likely aimed at guaranteeing political influence in the Executive to these institutions regardless of who wins the elections.

Another important point on the behavior of private banks in their political articulation concerns the institutional representation of these companies, in particular around the Brazilian Federation of Banks (Febraban), the main association of the sector. Although the institution is responsible for representing the banking sector of the country as a whole, there is evidence of overrepresentation by private domestic banks, at least superficially, in comparison with their foreign

${ }^{5} 5$ AGÊNCIA ESTADO. Empreiteiras e bancos foram maiores doadores a Lula. Estadão, online. 2006. Available at: https://politica.estadao.com.br/noticias/geral,empreiteiras-e-bancos-foram-maiores-doadores-alula,20061128p59780. Last access: 27 Aug 2019

Bancos são os maiores doadores da campanha de Alckmin. G1, online. 2006. Available at: http://g1.globo.com/Noticias/Politica/0,AA1368570-5601,00BANCOS+SAO+OS+MAIORES+DOADORES+DA+CAMPANHA+DE+ALCKMIN.html. Last access: 27 Aug 2019

NAVARRO, Silvio; ZANINI, Fábio. Setor bancário deu maior doação à campanha de Lula. Folha, online. 2006. Available at: https://www1.folha.uol.com.br/folha/brasil/ult96u87203.shtml. Last access: 27 Aug 2019

SALOMON, Marta; VALENTE, Rubens. Doação de bancos a PT cresceu cerca de $1000 \%$ desde 2002. Folha, online. 2006. Available at: https://www1.folha.uol.com.br/fsp/brasil/fc2702200602.htm. Last access: 27 Aug 2019 $56 \quad$ It is also bears noting that, even if the foreign players possibly presented higher levels of political activity in other fronts (such as through donations to members of Congress), which was not assessed in this paper, the direct connection of private institutions to the Executive in Brazil is still likely a better proxy for institutional influence given the high levels of fragmentation in the Legislative division in addition to the political power concentration in the Executive division historically in Brazil. 
competitors. Among all 14 presidents since its foundation, only 1 came from a foreign bank ${ }^{57}$ In the last 28 years, Febraban was chaired by executives linked to Itaú or Bradesco in 16 of them, with foreign banks having executives indicated by them chairing the institution in only 3 years. ${ }^{58}$. It is worth noticing that the period of the peak of the foreign banks' market share, in 2001, was precisely the one in which, according to Miranda (2003), there was a strong representation of these players in Febraban, counting with $33 \%$ of the board. Currently, this level is at $9 \% .{ }^{59}$

Table 6 - Febraban Presidents, selected years (1991-2018)

\begin{tabular}{lllr} 
Executive & Origin & Institution & Ternure \\
\hline Alcides Tápias & Private & Bradesco & $1991-1994$ \\
Mauricio Schulman & Public & Banco Nacional de Habitação & $1994-1997$ \\
Roberto Egydio Setubal & Private & Itaú & $1997-2001$ \\
Gabriel Jorge Ferreira & Private & Itaú & $2001-2004$ \\
Márcio Cypriano & Private & Bradesco & $2004-2007$ \\
Fábio Barbosa & Foreign & Santander & $2008-2011$ \\
Murilo Portugal & Public & Government & $2012-$ \\
\hline
\end{tabular}

Source: Febraban

The characterization by Dias (2015) about the dynamics of representation of the institution is also an important point to be addressed. According to him, in recent years it has been marked more by the direct protection of each banks' interests than by the construction of common consensuses or agendas within the federation - reinforcing the relevance of the political power inside the institution as a mean to shape its agenda towards the implementation of specific policies.

During his term, the then president of Itaú, who also presided over Febraban, Roberto Setúbal, stated:

Vejo positivamente a entrada desses bancos estrangeiros. Em primeiro lugar, acho que o sistema financeiro tornou-se mais sólido, o que é muito importante porque reduz percepção de risco que os investimentos estrangeiros têm no Brasil. [...] Eu entendo que um país como o Brasil deve ter um sistema financeiro preponderantemente nacional. Mas é preciso existir espaço para bancos estrangeiros de modo que haja mais competição, maior solidez e uma interação

57 Fábio Barbosa, from 2008 to 2011, who worked at ABN Amro and then at Santander.

$58 \quad$ Other terms in this period were served by Mauricio Schulman (1994-1997), from Banco Nacional da Habitação, and Murilo Portugal (2012-), who previously worked for the federal government.

${ }^{59}$ FENABRAN. Diretoria executiva. Undated. Available at: https://portal.febraban.org.br/paginas/68/pt-br/estruturadiretoria-executiva. Last access: 27 Aug 2019 
mais ampla com o mundo. Um mercado com até $30 \%$ de presença estrangeira (e ainda não temos esse nível hoje) me parece que pode ser uma situação de competição bastante boa e ao mesmo tempo uma presença nacional ainda predominante. (FSP, 7/2/1999: 35-36) ${ }^{60}$

Despite Setubal's preliminary positive characterization of foreign presence in the market, it should be highlighted its ideal market conception, with a 30\% maximum of foreign players participation - ensuring that the system remained "predominantly national". It should be noted in this regard that, although foreign participation was growing at that time, reaching its peak of $26.5 \%$ in 2001, it has never exceeded or even reached the $30 \%$ level indicated by the president of Febraban that year.

In January 2000, Febraban's chairman (1985-1987) and then owner of Banco BBA ${ }^{61}$ Fernão Bracher, ${ }^{62}$ declared to be directly against the opening of the banking market to foreign players conducted in the 1990s, defending the domestic dominance as an essential factor for the systemic stability of the banking market, in an interview with Folha de São Paulo: "I regret that the foreigners were authorized (referring to the Explanatory Note, mentioned in note $n$ 34). What we have nowadays is a substantial opening for international banks. I oppose it." (FSP, 02 January 2000). ${ }^{63}$

Therefore, it is reasonable to highlight the institution's behavior as an important element in the competitive characterization of the competitive panorama for foreign players in the Brazilian banking sector, not only through its representative structure background but also from isolated declarations of Febraban and its representatives. ${ }^{64}$

60 Translation by the author: I see positively the entry of these foreign banks [in the Brazilian market]. Firstly, I think the financial system has become more solid, which is very important because it reduces the perception of risk that foreign investments have in Brazil. [...] I understand that a country like Brazil must have a predominantly national financial system. But there needs to be room for foreign banks so that there is more competition, more solidity and wider interaction with the world. A market with up to $30 \%$ foreign presence (and we do not have this level today) seems to me to be a very good competition situation and at the same time still a predominant national presence.

$61 \quad$ Later acquired by Itaú, in 2002.

62 Fernão Bracher is also the father of Candido Bracher, who has been president of Itaú since 2016.

63 FRIEDLANDER, David; GRINBAUM, Ricardo. Banqueiro quer limite a estrangeiros. Folha, online. 2000. Available at: https://www1.folha.uol.com.br/fsp/dinheiro/fi0201200016.htm Last access: 27 Aug 2019

64 It bears noting that this work did not propose a thorough assessment of all possible statements the institution might have released concerning the topic. The priority was discussing remarks that, even though possibly isolated and not consensual within the institution, are by their own merits worth of note and relevant to the discussion proposed due to its broad representativity and possibility of impact on the the political and institutional agenda upheld by the sector. 
In general, the behavior of private banks matters in understanding the low participation of foreign banks in the Brazilian banking market, as (i) unlike state-owned banks, private domestic players tend to position themselves directly in the niches where foreigners operate, adopting aggressive behaviors in acquiring market shares, including through major M\&A operations; and (ii) there is clear evidence of an active and, to some extent, hostile behavior towards foreign competition by domestic players in political and institutional terms, which tends to materialize in competitive advantages vis-à-vis their foreign competitors, who in turn have presented historically lower levels of capacity (or will) to influence this environment over the past decades. 


\section{CASE STUDY: A COMPARISON BETWEEN SANTANDER BRASIL AND HSBC BRASIL}

Although it occupies the fifth place in terms of market share in Brazil, below its position in countries such as Chile (where it is the market leader), Portugal (where it occupies the second position) and Mexico (also second place), the Brazilian operation of Santander's is the most profitable among all of the group's, accounting for approximately one-quarter of its total profit in 2018. ${ }^{65}$ Since 2008, Santander Brasil has been the third largest private bank in the country in terms of total assets, and is therefore considered a case, if not the largest, of success among foreign financial institutions present in Brazil.

HSBC, on the other hand, despite being a prominent institution globally (recurrently leading the European market, for example), has a trajectory in Brazil that can be considered as erratic and unsuccessful - in this exercise indicated in terms of its exit from this market and aggravated by the significant losses in the period in which its main competitors operated with significant profit levels, in $2015 .^{66}$

The evolution of the total assets of the two institutions illustrates the difference of their trajectories - despite the similarity of their starting point - as indicated in Graph 04:

\section{Chart 7 - Total Assets per Year, Santander vs HSBC, 2000-2015, in BRL millions}

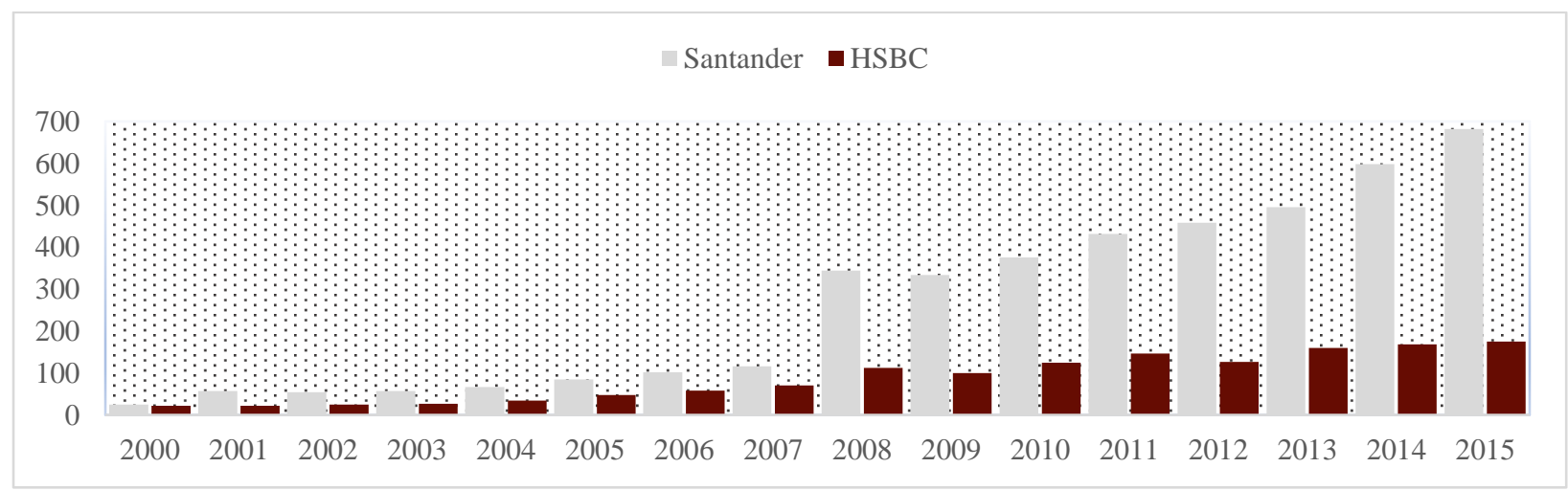

Source: BCB, author's elaboration

65 2019, Santander, The Banker, apud. Exame "Como o Santander tornou-se um dos maiores e mais rentáveis bancos do país", 14 de fevereiro de 2019. Santander Annual Report Available at: https://www.santanderannualreport.com/2015/en/annual-report/economic-and-financial-review/results-countriesand-businesses/mexico.html Last access: 27 Aug 2019

$66 \quad$ According to a report by Revista Exame (https://exame.abril.com.br/negocios/juntos-itau-bradesco-esantander-lucram-r-47-bilhoes/) Itaú, Bradesco and Santander all operated with positive margins in 2015, combining a total of BRL 47 billion profit in 2015, while HSBC presented losses of BRL 735.4 million, according to a report by Valor Econômico (https://www.valor.com.br/financas/4488690/hsbc-brasil-tem-prejuizo-37-maior-em-2015-der-7354-milhoes ). 
Considering the relative equivalence of global relevance of the two institutions - both in 2018 were among the 20 largest banks in the world in total assets, ${ }^{67}$ for instance - at the same time that they presented opposite trajectories in the Brazilian market, it is worth evaluating, for illustrative purposes of the exploratory discussion held in previous sessions, the strategic, institutional and circumstantial elements of the presence of these banks in the country.

\subsection{Santander Brasil}

Indirectly present in the Brazilian market since 1957, when it made an operational agreement with Banco Intercontinental do Brasil, Santander Brasil officially began its activities in the country in 1982, when it opened its first branch in São Paulo. Initially, however, its operation was concentrated in the activities of investment bank, having expanded its scope only from the decade of 1990.

From then on - and in light of the country's new opening scenario - the bank combined organic growth with an ambitious acquisitions' strategy. These included the purchases of Banco Geral do Comércio, in 1997; Banco Noroeste, in 1998; Banco Meridional, in 2000; and, particularly, the acquisition of Banespa in the same year (in the context of PROER and PROES). In 2007, Santander Group acquired the global operations of ABN Amro, which also culminated in the integration of the Brazilian operations of the two institutions. ${ }^{68}$

The success of the institution's Brazilian operation, here indicated mostly by its competitive survival in a market dominated by large and powerful domestic players, seems to be related to two central strategic elements, namely:

(i) a successful M\&A strategy since its establishment, focused on the acquisition of medium and large institutions that have provided the company with access, scale and capillarity in the country; and

(ii) a market-competitive positioning complementary to that of its private domestic rivals and at the same time similar to it in the sense of not competing in niches dominated by state-owned banks.

67 CHAUDHRY, Saqib; MEHMOOD, JahanZaib. The World's 100 Largest Banks. S\&P Global, online. 2018. Available at: https://www.spglobal.com/marketintelligence/en/news-insights/research/the-world-s-100-largest-banks Last access: 27 Aug 2019

68 The purchase included operations by Banco Real, which had been bought by the ABN Amro conglomerate in the previous decade. 
With regard to the role of acquisitions, the bank's operations with ABN Amro and Banespa are particularly noteworthy, as these movements represented large scale leaps for the institution an element that, as discussed, is directly related to lower costs and higher capabilities in addressing the sector challenges in the country (demographic, reputational and information). Between 2000 and 2001, for example, after the acquisition of Banespa, Santander saw its total number of branches jump from 421 to 1,018 - an increase of 142\%. Between 2007 and 2008, with the merger with ABN Amro, this indicator went from 1,086 to 2,405, increasing by more than $121 \% .{ }^{69}$ Taking as reference the basis of the discussion in section 4 , it is reasonable to conclude that the capillarity brought to Santander through these operations allowed it to acquire levels of local knowledge and reputation superior to those practiced by niche competitors, in turn concentrated in the capitals and financial centers of the country, such as São Paulo and Rio de Janeiro.

It should also be noted that Santander's expansion in Latin America was not restricted to the Brazilian market, with the bank having implemented a successful scale-up strategy in neighboring countries as well. According to Silva (2006), in the early 2000s, the bank started to reap the results of bank acquisitions in Argentina, Chile, Venezuela and Colombia, for example, occupying market share leadership positions in these markets. ${ }^{70}$

With regards to its market positioning strategy, it is important to highlight Santander's apparent continuous search for, roughly speaking, neglected market niches, or, to some extent, underexploited by its main domestic competitors - without, however, entering deeply into competition environments dominated by the public banks, such as specific credit segments.

In recent years, for example, the bank has successfully bet on the vehicle financing market, which is relatively less exploited by Itaú and Bradesco, presenting an increase of approximately $42 \%$ between 2016 and 2018 in this niche. It has also been the bank to offer the lowest personal credit rates for private individuals among the 3 largest private banks in the same period (72\% per year on average, versus $75 \%$ for Itaú and approximately $100 \%$ for Bradesco). ${ }^{71}$

69

${ }^{70}$ According to this author, such results came about after the acquisitions of Río de la Plata (Argentina), Banco da Venezuela (Venezuela), Inver-México (México) and Bancóquia (Colômbia), besides the merger with Banco Osorno, in Chile.

71 Data collected by Revista Época: GODOY, Denyse. Como o Santander tornou-se um dos maiores e mais rentáveis bancos do país. Revista Exame, online. 2019. Available at: https://exame.abril.com.br/revista-exame/ointruso/ Last access: 28 Aug 2019 
Also in line with the strategy of its main private conglomerate competitors, Santander has also worked for increasing the scope of its operations. In the last decade, for example, the bank deepened its presence in the insurance market (through a joint venture with German group HDI Insurances) and the credit card machine sector, largely dominated by private institutions, through the acquisition of GetNet, in 2014. Among the 5 largest banks in Brazil, only CEF does not have direct or indirect stakes in this sector.

Moreover, it is also worth noticing that Santander has sustained significant more conservative behavior in comparison with its main competitors over the past years, which reinforces the consistency of its strategic positioning - between 2008 and 2014 (last year with data available for this indicator), only in 2009 the bank did not present the highest Basel Indexes among the 5 largest banks in Brazil. $^{72}$

\subsection{HSBC Brasil}

HSBC officially started its operations in Brazil in 1976, through the representation office of Samuel Montagu. It was in 1997, however, that the bank effectively positioned itself in Brazil in permanent terms, through the acquisition of Banco Bamerindus, in the State of Paraná, also in the context of PROER and PROES. The acquisition gave the British bank the seventh position among the country's largest assets at the time, with a total of 1,200 branches initially (DIAS; LENZI; CORIGLIANO, 2011).

At the time of its entry, the then president of the Brazilian operation characterized the movement as part of a plan to position the institution as "Mercosur's largest commercial bank." 73 In 2003, he also said that Brazil was among the four priority countries for the group's worldwide expansion. ${ }^{74}$. That is to say its entrance was marked by an explicit attempt of the group of competing widely country's retail banking market with ambitious and, initially, a diversified strategy.

72 The Basel Index calculates the relationship between equity of reference and assets weightned by risks, and is often used as a proxy for the level of conservativeness of the banks as it reflects their solvency levels.

73 NAPOLITANO, Giuliana. "Não dá para competir no varejo", declara presidente do HSBC. Revista Exame, online. 2012. Available at: https://exame.abril.com.br/revista-exame/nao-da-para-competir-declara-presidente-dohsbc/. Last access: 28 Aug 2019

78 TREVISAN, Cláudia. HSBC compra Lloyds de olho no consumo. Folha, online. 2003. Available at: https://www1.folha.uol.com.br/fsp/dinheiro/fi1010200333.htm Last access: 28 Aug 2019 
In these two decades, however, HSBC fluctuated most of the time between the thirteenth and eighth positions in total assets of the country, a position it occupied when it sold its Brazilian operations to Bradesco in 2016. Among foreigners, it has always positioned behind Santander ${ }^{75 .}$

According to a Financial Times (FT) report, ${ }^{76}$, the British bank, which used to position itself globally as "the world's local bank", had its exit from the Brazilian market due to the difficulty of competing with the four largest domestic banks in the country, that is, due to not being able to replicate its globally adopted strategy in this market.

Although this movement followed a trend of reducing its operations in other emerging markets by HSBC (for instance, it left the Turkish market in the same year), the group's global CEO justified at that time the permanence of HSBC in the also Latin American Mexico, characterizing this country as "a more open market" and "with several reforms underway". This indicates that, while broad, the bank's strategic redirection towards a lower focus on emerging markets was, to some extent, conditioned to the local conditions of each market - reinforcing the pertinence of the discussion of the particular elements of the Brazilian market from this case.

In general terms, the Brazilian operation of the British group can be considered unsuccessful as, in addition to having culminated in its exit and not having met the expectations of market leadership announced upon its entry, it never generated profitability indicators similar to those of its local competitors - or even of its Spanish rival. In terms of scale, it is possible to say that the bank has reduced its reach since its establishment - at least on the basis of its physical presence, as will be discussed soon.

A strategic and market analysis of its trajectory in Brazil indicates that the difficulties of consolidating in the country are mostly related to:

(i) an erratic positioning in terms of reach and capillarity, without having made similar investments similar to its main retail competitors (e.g., through acquisitions that increase in scale and/or scope); and

(ii) a strategic approach of relative low autonomy and flexibility (with respect to its overall strategy), especially exacerbated by the bank's difficulty of incorporating particular challenges of

79 HSBC did not manage to individually surpass equally foreign AMB/Amro, bought by the Spanish group between 2007 and 2008 .

80 HSBC speeds up exit from emerging markets. Financial Times, online. 2016. Available at: https://www.ft.com/content/85642fcc-e50d-11e4-bb4b-00144feab7de Last access: 28 Aug 2019 
the Brazilian market and by the indirect effects of the Group's problematic operations in other markets.

According to Dias, Lenzi and Corigliano (2011), HSBC's control caused a "radical change" in Bamerindus' geographic expansion strategy that was in course until 1997. They claim that between 1996 and 2005 the number of municipalities integrated in the group network fell from 961 to 537, with the total number of agencies falling from 1,380 to 904. In its last year of operation, in 2016, there were 853 . Furthermore, the spatial analysis presented by them indicates that there had also been a high geographic concentration in a few centers, in especially in the southern region of Brazil and in São Paulo.

When interviewed by the Exame magazine in 2012, the then CEO of the bank, Conrado Engel, said: "We cannot compete at all with the big banks with approximately 870 branches. Bradesco and Itaú have more than 4,000. We need to make choices." 77

Considering such a statement in the face of the apparent deliberate bank strategy to reduce the presence HSBC inherited from Bamerindus', it is concluded that the bank HSBC faced, during its trajectory, reading difficulties or at least strategic consistency about the demands of the Brazilian market, likely concentrating its bets on the strength of its global brand rather than in adapting its operation to the country's demographic and economic context.

Moreover, there are no clear indications that the bank has undertaken significant initiatives towards expanding its operations scope, despite its initial intention to operate as a multiple bank. On the contrary, there are evidences that the bank has promoted a concentration of its operations, indicated for example by the sale in 2005 of its insurance subsidiary ("HSBC Seguros") to HDI Insurances (later associated to Santander). In 2011, the bank also dismantled its operations in the vehicle financing market, when it officially concentrated its operations in income-segments A and $\mathrm{B}$, betting on the presence and global capillarity of the institution as a differential for these income groups. ${ }^{78 .}$

In spite of isolated acquisitions, the bank never carried out particularly disruptive M\&A operations in the Brazilian financial market that could have promoted leaps in its market share in

$77 \quad$ NAPOLITANO, Giuliana. "Não dá para competir no varejo", declara presidente do HSBC. Revista Exame, online. 2012. Available at: https://exame.abril.com.br/revista-exame/nao-da-paracompetir-declara-presidente-do-hsbc/. Last access: 28 Aug 2019

$78 \quad$ NAPOLITANO, Giuliana. "Não dá para competir no varejo", declara presidente do HSBC. Revista Exame, online. 2012. Available at: https://exame.abril.com.br/revista-exame/nao-da-paracompetir-declara-presidente-do-hsbc/. Last access: 28 Aug 2019 
the country - the largest one, the acquisition of Lloyds in 2003, for instance, did not provide it with sufficient market share increase so that the bank could move up from the twelfth position in total assets it occupied that year. ${ }^{79}$.

With regards to Fachada's (2008) argument, above discussed, on the relevance of the quality of the assets that were acquired by foreigners when of their entries, it is important to highlight the assessment by Vidotto (2005, apud CARVALHO; VIDOTTO, 2007), which characterized as of good quality the assets portfolio that HSBC inherited from Bamerindus, indicating that this was likely not a significant factor for the discussion of the bank's success in the following years.

According to sources heard by these authors, the operation of HSBC in Brazil suffered from "serious problems related to the inadequacy of its branches network, to technological backwardness and difficulties with employee training", in addition to the consequences of a strategic conservatism nurtured by the bank's challenges in other countries. It is noteworthy that, given the nature of such problems, the bank does not seem to have implemented (or have been successful in implementing) a local and specific positioning strategy to address the challenges inherent in the Brazilian market.

On the same note, and in the institutional and structural dimension, the criticism made by the president of HSBC Brasil in 2000 to the competitive conditions of the country's banking market stands out. In an interview with Folha de São Paulo, he pointed out the difficulties identified by the bank in recovering credit, in complying with a labor legislation characterized by him as outdated (including the country's six-hour working day limitation), and the heightened levels of the Brazilian compulsory deposits (FSP, 8/8/2000, pp. B9 apud CARVALHO and VIDOTTO 2007).

Despite that, no significant initiatives in political terms by the bank were identified, as far as it was possible to determine over the course of this study, to significantly defend its interests at the institutional level - at least not in similar levels to that practiced by domestic banks. For example, the bank did not appear on the list of major donors in national election campaigns in the last decade (Table 4). There are also no clear evidences of significant leading further participation of Bank of America's assets management portfolio, Lloyd's operation portfolio, and Losango's national finance portfolio, all in 2003. 
by HSBC in the discussions of the agendas conducted by Febraban during the period when it operated in the country.

In line with the results of Claessens and Van Horen (2015), discussed in the previous sections, there is evidence that the performance of HSBC's Brazilian operations suffered from spillover effects of the difficulties faced by the group in other countries, according to official institution statements discussed in this section. Although this argument is, to some extent, contrary to the main hypothesis discussed in this dissertation, which considers the competitive dynamics of the Brazilian market as a central point in explaining the low participation of foreign banks in such market, it should be pointed out that HSBC's Brazilian operation did not become a priority in the group's portfolio, as opposed to what had been planned by the company when it entered the country - or, at least, alternatively, it may have become too complex to be successfully managed in parallel to the group's most pressing challenges in other countries.

Moreover, even if the bank's exit has been ultimately triggered by these external challenges, its operations in Brazil have been unsuccessful (in comparison with the bank's initial goals and with the results obtained by its direct competitor Santander) since its beginning, reinforcing the higher relevance of the country's competitive conditions in comparison with the bank's situation at its home country.

\subsection{Takeaways}

The distinct trajectories of Santander and HSBC highlight the relevance of certain competitive elements in the banking sector environment in Brazil. Although these may be assessed in the terms of their hierarchy in explaining the trajectories differences between these two banks in further works, they reinforce the main findings of this research. 
Chart 8 - Accumulated Net Profit (starting in 2000), 2000-2014; in BRL Millions

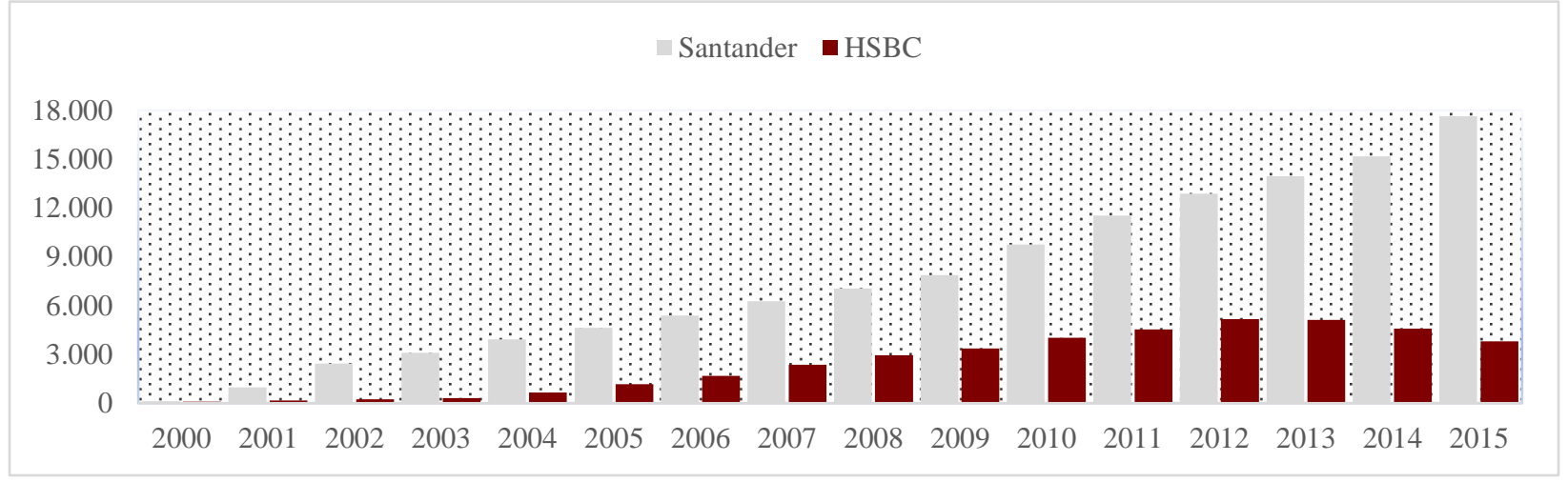

Source: BCB, author`s elaboration

Santander`s success in achieving capillarity (mainly by expanding its branches`network) at the same time HSBC seem not to have prioritized that, for instance, reinforce the importance of banks to actively pursue scale and scope gains in the Brazilian banking scenario.

Chart 9 - Branches share over total, 2000-2015

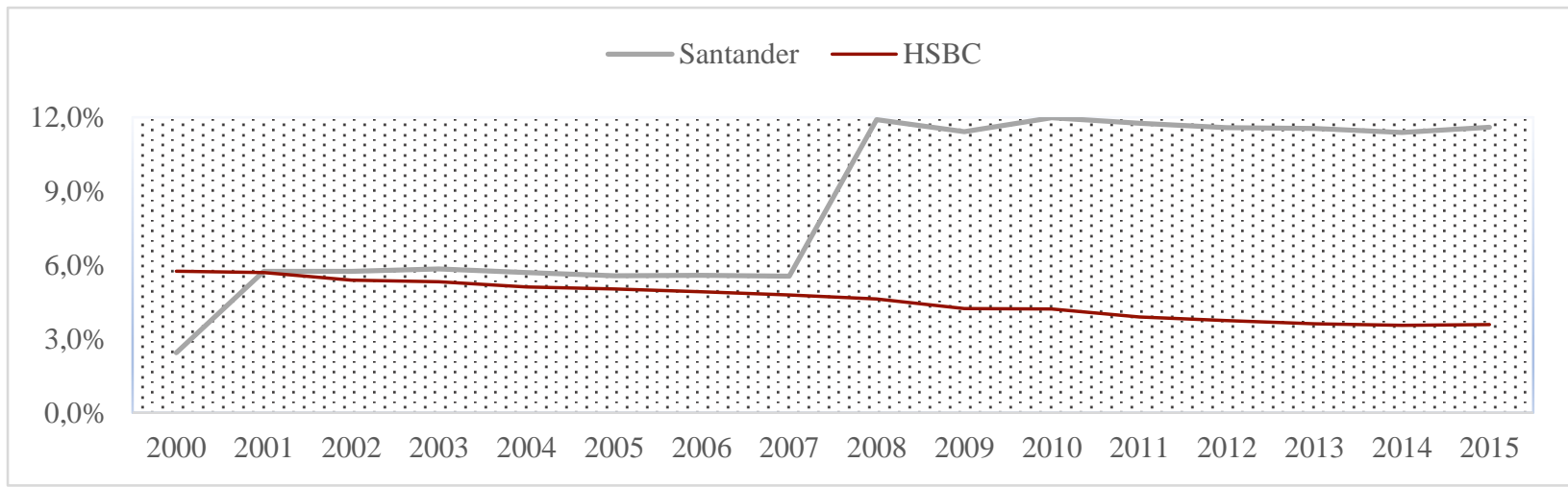

Source: BCB, author`s elaboration

Moreover, Santander`s suggested higher institutional activity levels in comparison to those indicated by the British bank also illustrates, at least preliminarily, the role of such sort of positioning in a competitive landscape that is marked by a hostile behavior by local banks in political terms.

Furthermore, the hardships faced by HSBC with regards to adapting its strategic orientation in real time, in terms of management flexibility, reinforces the role of the particularly high dynamism of the Brazilian banking sector`s; this has been likely related to the sui generis behavior by the public banks, who have set trends in the sector that have not always been necessarily predictable (as they do not always prioritize profit maximization), in addition to macro-regulatory 
instabilities occasionally promoted by the government in light of the high autonomy levels by regulation institutions, as discussion in section 4.1 . 


\section{FINAL CONSIDERATIONS}

The study of the Brazilian banking sector since the 1990's opening, focused on analyzing the competitiveness and the actual performance of large foreign institutions active in the retail segment, reinforces the high complexity levels of the sector's competitive environment.

The evidences here discussed indicate that foreign banks have suffered, over the past two decades, from significant difficulties in competing against local players. Despite isolated cases, such as the one of Santander - who seems to have successfully adapted to the Brazilian market's particularities - these challenges have played a role in explaining, ultimately, the low participation of foreign banks on the terms of their market shares in the country, particularly since 2007. They are also directly related to recent relevant foreign bank exits in Brazil, such as those of the global conglomerates Citibank and HSBC, both carried over between 2015 and 2017.

These competitive aspects can be summarized by (i) the sui generis structure (including in institutional terms) of the Brazilian banking market, which has been increasingly marked by high levels of concentration; (ii) the prominent role of state-owned banks, which, in addition to acting as agenda setters in the market and exerting significant influence over risk taking trends, have dominated specific niches in the market; and (iii) the defensive and, at the same time, aggressive behavior by the local players in the sense of actively protecting their dominance over the market, mostly through M\&A operations and through a proactive institutional positioning that has not been followed, at least not to the same extent, by foreign competitors of the sector. These elements combined have undermined the competitiveness of such institutions, which have thus incurred ultimately in lower performance levels (including in profitability terms) vis-à-vis the private and state-owned local competitors.

However, the lack of definitive legal barriers to the entry of foreign banks in the Brazilian banking sector - despite the discussed bureaucratic hardships in this regard - in addition to the relatively higher presence of foreign banks over the past two decades (in number of institutions $41 \%$ of the country`s total in 2018, vis-à-vis $31 \%$ in 2000) indicate that this is not a sector with necessarily high levels of barriers to entry. Their low and decreasing competitiveness over this period suggest that their challenges are more likely related to barriers to perform (or, ultimately, barriers to stay), specifically, as opposed to the sector being essentially closed to them in broad terms. 
Although the differentiation of such concepts may seem problematic - in the sense that competitive challenges affecting players of a sector after their entries are consensually characterized, ultimately, as barriers to entry, according to the widely consensual microeconomic literature - some elements of the Brazilian banking market suggest that it presents competitive particularities that are not necessarily applied, specifically, to the initial operations of new players, but to their long-term performance sustainability. For instance, the need of continuous capillarity development (through scale and scope gains) and of a permanent political and institutional activity indicate that, although several banks may be successful in achieving sustainable profit levels in specific niches over certain periods, the direct competition against the markets largest players in the long run require strategic positionings precisely aimed at providing them with competitive differentiations vis-à-vis the sector`s strongest competitors. One empirical evidence for that is the fact that the foreign institutions that entered the market aiming at leading the market - which had, by the way, the theoretical conditions for that (in terms of size and global expertise) - such as Citibank and HSBC, had to reassess their presences in Brazil when faced with the direct hostility by their private competitors, namely Itaú and Bradesco. Moreover, Bank of America`s decision to terminate its operations in the country but to continue invested in the Brazilian banking sector through its stakes in Itaú also highlights, in directly, the same phenomenon.

While this hypothesis is suggested (without deep testing) in parallel to the main conclusions of this research (and thus needs, of course, to be further developed, in theoretical terms), it is consistent with its main findings. Although foreign banks continue to enter the Brazilian market, they have not faced a favorable - or even a neutral - competition environment in the country recently. This indicates that their decreasing performance levels (and hence their falling market shares) over the past two decades are likely not a result of external factors, but are essentially related to endogenous dynamics of the Brazilian banking sector. 


\section{REFERENCES}

AGÊNCIA ESTADO. Empreiteiras e bancos foram maiores doadores a Lula. Estadão, online. 2006. Available at: https://politica.estadao.com.br/noticias/geral,empreiteiras-e-bancosforam-maiores-doadores-a-lula,20061128p59780. Last access: 27 Aug 2019

ALVES, Aluísio. Bank of America sairá do capital do Itaú Unibanco. Revista Exame, online. 2010. Available at: https://exame.abril.com.br/mercados/bank-of-america-saira-capitalitau-unibanco-560971/. Last access: 27 Aug 2019

ARAÚJO, Carlos Alberto Gonçalves de; GOLDNER, Fábio; BRANDÃO, Marcelo Moll; et al. Estratégia de fusão e aquisição bancária no Brasil: evidências empíricas sobre retornos. Contextus - Revista Contemporânea de Economia e Gestão, v. 5, n. 2, 2007.

ARAUJO, De; LEONARDO, Victor; LOBATO, Denise. Avanços, recuos, acertos e erros: Uma análise da resposta da política econômia brasileira à crise financeira internacional. Brasília: [s.n.], 2011.

BANCO CENTRAL DO BRASIL. Bancos Brasileiros após a Resolução 1524, de 21.09.88.

[s.l.: s.n., s.d.]. Available at: http://www.bcb.gov.br/htms/deorf/e882000/texto.asp?idpai=RELSFN19882000. Last access: 20 Aug 2019

Bancos são os maiores doadores da campanha de Alckmin. G1, online. 2006. Available at: http://g1.globo.com/Noticias/Politica/0,,AA1368570-5601,00BANCOS+SAO+OS+MAIORES+DOADORES+DA+CAMPANHA+DE+ALCKMIN.ht ml. Last access: 27 Aug 2019

BANCO CENTRAL DO BRASIL. PROER - Programa de Estímulo à Reestruturação e ao Fortalecimento do Sistema Financeiro Nacional. Available at: https://www.bcb.gov.br/htms/proer.asp. Last access: 20 Aug 2019

BANCO CENTRAL DO BRASIL. Relatório de Economia Bancária. [s.l.: s.n.], 2017. Available at http://www.bcb.gov.br/pec/depep/spread/REB_2017.pdf. Last access: 20 Aug 2019

BARBOSA, Klenio; ROCHA, Bruno; SALAZAR, Fernando. Assessing Competition in the Banking Industry: A Multi-Product Approach Bruno Rocha Assessing Competition in the Banking Industry. São Paulo: [s.n.], 2013. Available at 
https://cmicro.fgv.br/sites/cmicro.fgv.br/files/arquivos/WP_10_2013.pdf. Last access: 20 Aug 2019

BECK, Thorsten; CRIVELLI, Juan Miguel; SUMMERHILL, William. State bank transformation in Brazil - Choices and consequences. Journal of Banking and Finance, v. 29, n. 8-9 SPEC. ISS., p. 2223-2257, 2005.

BECK, Thorsten; MARTINEZ PERIA, Maria Soledad. Foreign bank participation and outreach: Evidence from Mexico. Journal of Financial Intermediation, v. 19, n. 1, p. 52-73, 2010.

BERGER, Allen N; KLAPPER, Leora F; SOLEDAD, Maria; et al. Bank ownership type and banking relationships. World Bank Policy Research Working Paper, v. 1, p. 1-26, 2007.

BHATTACHARYA, Joydeep. the Role of Foreign Banks in Developing Countries: A Survey of the Evidence. Unpublished manuscript, Cornell University, 1993.

BOEHE, DIRK MICHAEL; CUNHA, Sebastião. Why do Banks Internationalize? The Distinctive Strategy of a Brazilian Retail Bank. XXXII Encontro da ANPAD, p. 1-16, 2008.

BRONZATI, Aline; CARVALHO, Renato; SCARAMUZZO, Mônica. Banco Central aprova compra do Citibank pelo Itaú Unibanco. Estadão, online. 2017. Available at: https://economia.estadao.com.br/noticias/negocios,banco-central-aprova-compra-docitibank-pelo-itau-unibanco,70002061930. Last access: 27 Aug 2019

BUCH, Claudia M; KOCH, Cathérine T; KOETTER, Michael. Do banks benefit from internationalization? Revisiting the market power-risk nexus. Review of Finance, v. 17, n. 4, p. 1401-1435, 2013.

CARVALHO, Carlos Eduardo; VIDOTTO, Carlos Augusto. Abertura do setor bancário ao capital estrangeiro nos anos 1990: os objetivos e o discurso do governo e dos banqueiros. v. 17, n. 3, 2007. Available at: http://www.scielo.br/scielo.php?pid=S010363512007000300002\&script=sci_arttext\&tlng=pt. Last access: 20Aug 2019

CARVALHO, Fernando Cardim. New competitive strategies of foreign banks in large emerging eonomie: the case of Brazil. Banca Nazionale del Lavoro Quarterly Review, v. 213, p. 135-169, 2000. 
CASTRO, Fernanda; KALATZIS, Aquiles E G; MARTINS-FILHO, Carlos. Financing in an emerging economy: Does financial development or financial structure matter? Emerging Markets Review, v. 23, p. 96-123, 2015

CHAUDHRY, Saqib; MEHMOOD, JahanZaib. The World's 100 Largest Banks. S\&P Global, online. 2018. Available at: https://www.spglobal.com/marketintelligence/en/newsinsights/research/the-world-s-100-largest-banks Last access: 27 Aug 2019

CLAESSENS, S; DEMIRGUC-KUNT, A; HUIZINGA, Harry. How Does Foreign Entry Affect the Domestic Banking Market? Stijn Claessens, Asli Demirgüç-Kunt, and Harry Huizinga. Journal of Banking and Finance, v. 25, n. May, p. 891-911, 2001.

CLAESSENS, Stijn; HOREN, Neeltje Van; GURCANLAR, Tugba; et al. Foreign Bank Presence in Developing Countries 1995-2006: Data and Trends. [s.l.: s.n.], 2008. Available at: http://ssrn.com/abstract=1107295. Last access: 20Aug 2019

CLAESSENS, Stijn; VAN HOREN, Neeltje. Foreign Banks: Trends, Impact and Financial Stability. DNB Working Paper Series, n. 330, 2012.

CLAESSENS, STIJN; VAN HOREN, Neeltje. The Impact of the Global Financial Crisis on Banking Globalization. IMF Economic Review, v. 63, n. 4, 2015.

CLARKE, GEORGE; CULL, ROBERT; MARTINEZ, MARIA; SÁNCHEZ, Susana. Foreign Bank Entry: Experience, Implications for Developing Economies, and Agenda for Further Research. The World Bank Research Observer, v. 18, n. 1, p. 25-59, 2003. COELHO, Christiano A; MELLO, João M P De; REZENDE, Leonardo B. Do Public Banks Compete with Private Banks? Evidence from Concentrated Local Markets in Brazil. [s.1.: s.n.], 2011. Available at: <http://reap.org.br/wp-content/uploads/2011/11/002-DoPublic-Banks-Can-Compete.pdf>. Last access: 20Aug 2019

CORTES, Gustavo S.; PAIVA, Claudio AC. Deconstructing credibility: The breaking of monetary policy rules in Brazil. Journal of International Money and Finance, v. 74, p. 31-52, 2017.

CRYSTAL, Jennifer S; DAGES, B Gerard; GOLDBERG, Linda S. Has foreign bank entry led to sounder banks in Latin America? Current Issues in Economics and Finance, v. 8, n. 1, p. 1-6, 2002.

CULL, Robert; PERIA, Maria Soledad Martinez; VERRIER, Jeanne. Bank Ownership: Trends and Implications. IMF Working Paper Series, 2017. 
DAS, Santosh Kumar. Financial Liberalization and Banking Sector Efficiency: The Indian

Experience. [s.l.: s.n.], 2010. Available at: http://www.igidr.ac.in/conf/money/mfc12/Financial.

DE HAAS, Ralph; VAN LELYVELD, Iman. Foreign banks and credit stability in Central and Eastern Europe. A panel data analysis. Journal of Banking and Finance, v. 30, n. 7, p. 1927-1952, 2006.

DIAS, Rodolfo Palazzo. A representação dos banqueiros no Brasil: um estudo sobre a FEBRABAN. Teoria e Pesquisa, p. 178-204, 2014.

FACHADA, Pedro. Foreign Banks' Entry And Departure - The Recent Brazilian Experience 1996-2006. [s.1.: s.n.], 2008.

FENABRAN. Diretoria executiva. Undated. Available at: https://portal.febraban.org.br/paginas/68/pt-br/estrutura-diretoria-executiva. Last access: 27 Aug 2019

FRIEDLANDER, David; GRINBAUM, Ricardo. Banqueiro quer limite a estrangeiros. Folha, online. 2000. Available at: https://www1.folha.uol.com.br/fsp/dinheiro/fi0201200016.htm Last access: 27 Aug 2019

FREITAS, Maria Cristina Penido De; PRATES, Daniela Magalhães. A abertura financeira no governo FHC: impactos e conseqüências. Economia e Sociedade, v. 10, n. 2(17), p. 81$111,2001$.

FREITAS, MARIA CRISTINA PENIDO; PRATES, Daniela. Abertura financeira na América Latina: as experiências da Argentina, Brasil e México. Economia e Sociedade, n. 2, p. 173-198, 1998.

FREITAS, Otávio Dias. Performance dos bancos brasileiros no contexto de digitalização. Dissertação (Mestrado em Economia) - Universidade Federal do Rio Grande do Sul, Escola de Economia, Porto Alegre, 2018.

GALLAGHER, Kevin P; PRATES, Daniela Magalhães. Financialization and the Resource Curse: The Challenge of Exchange Rate Management in Brazil. Boston: [s.n.]. Available at: https://www3.bcb.gov.br/sisorf_externo/manual/11-09-020-001.htm. Last access: 20Aug 2019 
GEHRINGER, Agnieszka. Financial Liberalization, Financial Development and Productivity Growth - An Overview. International Journal of Monetary Economics and Finance, v. 7, n. 1, p. 40-65, 2014.

GODOY, Denyse. Como o Santander tornou-se um dos maiores e mais rentáveis bancos do país. Revista Exame, online. 2019. Available at: https://exame.abril.com.br/revista-exame/ointruso/ Last access: 28 Aug 2019

GONZÁLES, Pablo; LUCCHESI, Cristiane. Santander se prepara para comprar ativos do Citi no país. Revista Exame, online. 2016. Available at:

https://exame.abril.com.br/negocios/santander-se-prepara-para-comprar-ativos-do-citino-pais/. Last access: 27 Aug 2019

GOPALAN, Sasidaran. Financial liberalization and foreign bank entry in emerging and developing economies: What does the literature tell us? Journal of International Commerce, Economics and Policy, v. 06, n. 02, p. 1550007, 2015.

GROSSMAN, Gene M; HELPMAN, Elhanan. Protection for Sale. The American Economic Review, v. 84, n. 4, p. 833-850, 1994.

HSBC speeds up exit from emerging markets. Financial Times, online. 2016. Available at: https://www.ft.com/content/85642fcc-e50d-11e4-bb4b-00144feab7de Last access: 28 Aug 2019

IANONI, Marcus. Ciência Política e sistema financeiro no Brasil: o artigo 192 da Constituição Federal. Política \& Sociedade, v. 9, n. 17, p. 173-204, 2010.

INTERNATIONAL MONETARY FUND, Country Report No. 19/48, 2019.

Itaú desbanca Santander e fica mais perto de levar Citi Brasil. Infomoney, online. 2016. Available at: https://www.infomoney.com.br/mercados/acoes-eindices/noticia/5558620/itau-desbanca-santander-fica-mais-perto-levar-citi-brasil. Last access: 27 Aug 2019

JAMES R. BARTH, GERARD CAPRIO JR., Ross Levine. Banking Systems around the Globe: Do Regulation and Ownership Affect Performance and Stability? [s.l.: s.n.], 2006. Available at: http://www.nber.org/chapters/c10757.pdf. Last access: 20Aug 2019

JUNIOR, Carlos Alberto Leite. Uma análise do PROER 20 anos depois. Dissertação (Mestrado em Economia) - Universidade de Brasília, Brasília, 2016. 
JUNIOR, Cleofas Salviano. Bancos Estaduais: dos Problemas Crônicos ao Proes. [s.1.: s.n.], 2004. Available at:

https://www.bcb.gov.br/htms/public/BancosEstaduais/livro_bancos_estaduais.pdf. Last access: 20Aug 2019

KOSE, M. Ayhan; PRASAD, Eswar S.; TAYLOR, Ashley D. Thresholds in the process of international financial integration. Journal of International Money and Finance, v. 30, n. 1, p. 147-179, 2011.

KOSE, M. AYHAN; PRASAD, ESWAR S.; TERRONES, Marco E. Financial Integration and Macroeconomic Volatility. Working Paper - International Monetary Fund, v. 50, n. 2003, p. 119-142, 2009.

LAEVEN, Luc; KLINGEBIEL, Daniela. Managing the Real and Fiscal Effects of Banking Crises. [s.1.: s.n.], 2002.

LANE, Philip R; MILESI-FERRETTI, Gian Maria. International Financial Integration in the Aftermath of hte Global Financial Crisis. IMF Working Paper, v. 17, n. 115, p. 1-53, 2017.

LEVINE, Ross. Negando a la Entrada a la Banca Extranjera: Implicaciones para los Margeneres de Interes Bancarios. Banco de México Documento de Investigación, n. 2006-11, 2001.

LIMA, Marcus Vinicius de Souza. Estratégias competitivas do sistema bancário privado do Brasil pós-estabilização, segundo Michael Porter: uma análise dos principais bancos. Monografia (Trabalho de conclusão de curso) - Universidade Federal da Bahia, 2008. Disponível em: 〈https://repositorio.ufba.br/ri/bitstream/ri/9801/1/TCC〉.

MAIA, Geraldo Villar Sampaio. Reestruturação Bancária no Brasil: o Caso do PROER. [s.1.: s.n.], 2003. Available at https://www.bcb.gov.br/pec/notastecnicas/port/2003nt38ReestrutBancBrasilp.pdf. Last access: 20Aug 2019

MAIA, Geraldo Villar Sampaio. Restructuring the banking system - the case of Brazil. Bank Restructuring in Practice, n. 6, p. 106-123, 1999.

MANSFIELD, Edward D; MILNER, Helen V. The New Wave of Regionalism. International Organization, v. 53, n. 3, p. 589-627, 1999. 
MARINHO, Helder; LUCCHESI, Cristiane. Bradesco compraria HSBC de novo mesmo pagando mais, diz Lazari. UOL Economia, online. 2018. Available at: https://economia.uol.com.br/noticias/bloomberg/2018/11/14/bradesco-compraria-hsbcde-novo-mesmo-pagando-mais-diz-lazari.htm. Last access: 27 Aug 2019

MARQUES, Felipe. HSBC Brasil tem prejuízo 37\% maior em 2015, de R\$ 735,4 milhões. Valor Econômico, online. 2016. Available at: https://www.valor.com.br/financas/4488690/hsbc-brasil-tem-prejuizo-37-maior-em2015-de-r-7354-milhoes. Last access: 27 Aug 2019

MAZZUCATO, Mariana; PENNA, Caetano C R. Beyond Market Failures: The Market Creating and Shaping Roles of State Investment Banks. [s.1.: s.n.], 2015. Available at: http://www.levyinstitute.org/pubs/wp_831.pdf. Last access: 20Aug 2019

MCCAULEY, Robert N; BÉNÉTRIX, Agustín S; PATRICK, M. Financial deglobalisation in banking? [s.1.: s.n.], 2017. Available at: https://www.bis.org/publ/work650.pdf. Last access: 20Aug 2019

MESQUITA, Mário. A política econômica do governo Dilma: a volta do experimentalismo. In: PÚBLICAS, Centro de Debate de Políticas (Org.). Coletânea de capítulos da agenda “Sob a Luz do Sol". [s.1.: s.n.], 2014.

METTERNHEIM, Kurt E. von. Federal Banking in Brazil: Policies and Competitive Advantages. Boca Raton: CRC Press, 2016.

MICCO, Alejandro; PANIZZA, Ugo; YAÑEZ, Monica. Bank ownership and performance. Does politics matter? Journal of Banking and Finance, v. 31, n. 1, p. 219-241, 2007.

MINISTÉRIO DA FAZENDA. Conselho Monetário Nacional - CMN. Undated. Available at: http://www.fazenda.gov.br/assuntos/cmn. Last access: 27 Aug 2019

MIRANDA, Elflay. Globalização financeira e associações de bancos no Brasil: o caso da Febraban. Sociedade e Cultura, v. 6, n. 2 (jul-dez), p. 201-214, 2003.

NASSIF, André; CASTILHO, Marta. Trade patterns in a globalized world: the case of Brazil. BNDES discussion papers, 2018.

NAPOLITANO, Giuliana. "Não dá para competir no varejo", declara presidente do HSBC. Revista Exame, online. 2012. Available at: https://exame.abril.com.br/revista-exame/naoda-para-competir-declara-presidente-do-hsbc/. Last access: 28 Aug 2019 
NAVARRO, Silvio; ZANINI, Fábio. Setor bancário deu maior doação à campanha de Lula. Folha, online. 2006. Available at: https://www1.folha.uol.com.br/folha/brasil/ult96u87203.shtml. Last access: 27 Aug 2019 OBSTFELD, Maurice. Risk Taking, Global Diversification, and Growth. Minneapolis: [s.n.], 1992. Available at: https://www.minneapolisfed.org/research/dp/dp61.pdf. Last access: 20Aug 2019

PAULA, Ana; ARAUJO, Utasi. Análise da Rentabilidade no Setor Bancário Brasileiro / Profitability analysis in the Brazilian banking sector. 2018.

PAULA, Luiz Fernando de. Tamanho, dimensão e concentração do sistema bancário no contexto de alta e baixa inflação no Brasil. Nova Economia, v. 8, n. May, p. 87-116, 1998.

PAULA, Luiz Fernando de; ALVES, José Antônio. The determinants and effects of foreign bank entry in Argentina and Brazil: a comparative analysis +. Investigación Económica, v. 66, n. 259, p. 63-102, 2007.

PAULA, Luiz Fernando de; MEYER, Tiago Rinaldi. Liberalização financeira, performance econômica e estabilidade macroeconômica no Brasil: uma avaliação do período 19942007. Revista Nova Economia, v. 22, n. 3, p. 561-596, 2012.

PAULA, Luiz Fernando de. Estrutura do setor bancário e o ciclo recente de expansão do crédito: O papel dos bancos públicos federais. Revista Nova Economia, v. 23, n. 3, 2013.

PERIA, Martinez; CULL, Robert J. Foreign Bank Participation in Developing Countries: What Do We Know about the Drivers and Consequences of This Phenomenon ? World Bank Policy Research Working Paper, v. 5398, n. August, p. 5398, 2010.

POGHOSYAN, Tigran; POGHOSYAN, Arsen. Foreign bank entry, bank efficiency and market power in Central and Eastern European Countries. Economics of Transition, v. 18, n. 3, p. 571-598, 2010.

PORTES, Ivone. JP Morgan reduz atuação no Brasil com venda de carteira ao Bradesco. Folha, online. 2003. Available at: https://www1.folha.uol.com.br/folha/dinheiro/ult91u62620.shtml. Last access: 27 Aug 2019

POSSAS, Maria Silva. Concorrência e elementos subjetivos. Revista de Economia Política, v. 18, n. 4(72), p. 96-110, 1998.

POSSAS, Mario Luiz. Estruturas de Mercado em Oligopólio. São Paulo: Hucitec, 1985. 
PRATES, Daniela. A abertura financeira dos países periféricos e os determinantes dos fluxos de capitais. Revista de Economia Política, v. 19, n. 1, 1999.

RIBEIRO, Alex. Estrangeiro tem fila para entrar no país. Valor Econômico, online. 2013. Available at: https://www.valor.com.br/financas/3326156/estrangeiro-tem-fila-paraentrar-no-pais. Last access: 27 Aug 2019

RIBEIRO, Alex; SALES, Robson. Governo estuda simplificar entrada de banco estrangeiro, diz Ilan. Valor Econômico, online. 2017. Available at: https://www.valor.com.br/financas/4913436/governo-estuda-simplificar-entrada-debanco-estrangeiro-diz-ilan. Last access: 27 Aug 2019

SALOMON, Marta; VALENTE, Rubens. Doação de bancos a PT cresceu cerca de $1000 \%$ desde 2002. Folha Online. 2006. Available at: https://www1.folha.uol.com.br/fsp/brasil/fc2702200602.htm. Last access: 27 Aug 2019

SANCHES, Fabio Miessi; SILVA, Daniel Junior; SRISUMAX, Sorawoot. Bank Privatization and Market Structure of the Banking Industry: Evidence from a Dynamic Structural Model. [s.1.: s.n.], 2016.

SCHNEIDER, Ben Ross; LIMA-DE-OLIVEIRA, Renato; ALMEIDA, Mansueto. Política industrial e empresas estatais no Brasil: BNDES e Petrobras. Brasília: [s.n.], 2014. Available at: https://www.econstor.eu/bitstream/10419/121585/1/814789773.pdf.

\section{Last access: 20Aug 2019}

SILVEIRA, Pedro Paulo Bartolomei da. Concentração e competição bancárias no Brasil: uma aplicação do modelo Panzar-Rosse. Dissertação (Mestrado em Economia) - Fundação Getúlio Vargas, São Paulo, 2017.

STIGLITZ, Joseph E. The role of the state in financial markets. In: Proceedings of the World Bank Annual Conference on Development Economics. [s.1.: s.n.], 1993, v. 7, p. 19-62. Available at: http://documents.worldbank.org/curated/en/239281468741290885/pdf/multipage.pdf. Last access: 20Aug 2019

STURM, Jan Egbert; WILLIAMS, Barry. Foreign bank entry, deregulation and bank efficiency: Lessons from the Australian experience. Journal of Banking and Finance, v. 28, n. 7, p. 1775-1799, 2004. 
SUBSCRETARIA DE TRIBUTAÇÃO E CONTENCIOSO. IOF (Imposto sobre Operações de Crédito, Câmbio e Seguro, ou relativas a Títulos ou Valores Mobiliários). 2015. Available at: http://receita.economia.gov.br/acesso-rapido/tributos/IOF. Last access: 27 Aug 2019

TABAK, Benjamin Miranda; GOMES, Guilherme Maia Rodrigues; JÚNIOR, Maurício da Silva Medeiros. The Impact of Market Power at Bank Level in Risk-taking: the Brazilian Case. Brasília: [s.n.], 2012. Available at: https://www.bcb.gov.br/pec/wps/ingl/wps283.pdf. Last access: 20Aug 2019

TELES, Andrea Sequeira. Banking Internationalization in Latin America: The Brazilian case, 1997-2007 a panel analysis. Universidade Técnica de Lisboa, 2011.

TREVISAN, Cláudia. HSBC compra Lloyds de olho no consumo. Folha, online. 2003. Available at: https://www1.folha.uol.com.br/fsp/dinheiro/fi1010200333.htm Last access: 28 Aug 2019

WORLD BANK, Global Financial Development Database, 2013. 